\title{
Measurement report: Long-term measurements of aerosol precursor concentrations in the Finnish subarctic boreal forest
}

\author{
Tuija Jokinen ${ }^{1,2}$, Katrianne Lehtipalo ${ }^{1,3}$, Roseline Cutting Thakur ${ }^{1}$, Ilona Ylivinkka ${ }^{1}$, Kimmo Neitola $^{1}$, \\ Nina Sarnela ${ }^{1}$, Totti Laitinen ${ }^{1}$, Markku Kulmala ${ }^{1}$, Tuukka Petäjä ${ }^{1}$, and Mikko Sipilä ${ }^{1}$ \\ ${ }^{1}$ Institute for Atmospheric and Earth System Research (INAR)/Physics, Faculty of Science, \\ University of Helsinki, 00014 Helsinki, Finland \\ ${ }^{2}$ Climate \& Atmosphere Research Centre (CARE-C), The Cyprus Institute, 1645 Nicosia, Cyprus \\ ${ }^{3}$ Finnish Meteorological Institute, 00560 Helsinki, Finland \\ Correspondence: Tuija Jokinen (t.jokinen@cyi.ac.cy)
}

Received: 27 August 2021 - Discussion started: 13 September 2021

Revised: 21 January 2022 - Accepted: 22 January 2022 - Published: 18 February 2022

\begin{abstract}
Aerosol particles form in the atmosphere via the clustering of certain atmospheric vapors. After growing into larger particles by the condensation of low-volatility gases, they can affect the Earth's climate by scattering light and acting as cloud condensation nuclei $(\mathrm{CCN})$. Observations of low-volatility aerosol precursor gases have been reported around the world, but longer-term measurement series and any Arctic data sets showing seasonal variation are close to nonexistent. Here, we present $\sim 7$ months of aerosol precursor gas measurements performed with a nitrate-based chemical ionization atmospheric pressure interface time-of-flight (CI-APi-TOF) mass spectrometer. We deployed our measurements $\sim 150 \mathrm{~km}$ north of the Arctic Circle at the SMEAR I (Station for Measuring Ecosystem-Atmosphere Relations) continental Finnish subarctic field station, located in the Värriö strict nature reserve. We report concentration measurements of the most common compounds related to new particle formation (NPF): sulfuric acid (SA), methane sulfonic acid (MSA), iodic acid (IA) and the total concentration of highly oxygenated organic molecules (HOMs). At this remote measurement site, SA originates from both anthropogenic and biological sources and has a clear diurnal cycle but no significant seasonal variation. MSA shows a more distinct seasonal cycle, with concentrations peaking in the summer. Of the measured compounds, IA concentrations are the most stable throughout the measurement period, except in April during which time the concentration of IA is significantly higher than during the rest of the year. Otherwise, IA has almost identical daily maximum concentrations in spring, summer and autumn, and on NPF event or non-event days. HOMs are abundant during the summer months and low in the autumn months. Due to their low autumn concentrations and high correlation with ambient air temperature, we suggest that most HOMs are products of biogenic emissions, most probably monoterpene oxidation products. NPF events at SMEAR I happen under relatively low-temperature $\left(1-8{ }^{\circ} \mathrm{C}\right)$ conditions, with a fast temperature rise in the early morning hours as well as lower and decreasing relative humidity (RH, $55 \%$ vs. $80 \%$ ) during NPF days compared with non-event days. NPF days have clearly higher global irradiance values $\left(\sim 450 \mathrm{~m}^{-2}\right.$ vs. $\left.\sim 200 \mathrm{~m}^{-2}\right)$ and about $10 \mathrm{ppbv}$ higher ozone concentrations than non-event days. During NPF days, we have, on average, higher SA concentrations, peaking at noon; higher MSA concentrations in the afternoon; and slightly higher IA concentration than during non-event days. In summary, these are the first long-term measurements of aerosol-forming vapors from SMEAR I in the subarctic region, and the results of this work will help develop an understanding of atmospheric chemical processes and aerosol formation in the rapidly changing Arctic.
\end{abstract}




\section{Introduction}

The climate of the subarctic region is characterized by some of the most extreme temperature variations on Earth. During the course of the 21 st century, it is expected that the boreal forest will experience the largest temperature increases of all forest biomes (IPCC, 2013), making it the most vulnerable to climate change. The boreal forest (taiga) covers most of the subarctic and encompasses more than $30 \%$ of all forests on Earth, making it one of the largest biomes in the world (Brandt et al., 2013). The expected rate of change may overwhelm the resilience of forest ecosystems and possibly lead to significant biome-level changes (Reyer et al., 2015). The forest-atmosphere systems are also closely interlinked with one another: the forest stores carbon and water in the peat, soil and as biomass, while vegetation concurrently emits volatile organic compounds (VOCs) into the atmosphere (Bradshaw and Warkentin, 2015). In the Arctic, the summer is short, but solar radiation is abundant and extends the daylight hours to midnight and beyond. On the other hand, during the polar night, air pollutants accumulate in the atmosphere due to a cold and stable atmospheric conditions, while turbulent mixing is inhibited, and the lack of removal processes lead to the formation of Arctic haze (Stohl, 2006). These features make the Arctic an interesting study region with respect to the photochemistry of reduced atmospheric compounds. Oxidation processes that dominantly occur in the summertime control the processes removing VOCs and other traces gases, such as $\mathrm{SO}_{2}$ and $\mathrm{NO}_{x}$, from the atmosphere in the Arctic. Thus, a detailed understanding of the atmospheric processes leading to aerosol precursor formation and gas-to-particle conversion as well as their role in feedback mechanisms would help with assessing the future climate.

Aerosol and trace gas measurements at the SMEAR I subarctic field station began in 1992 (Ahonen et al., 1997; Kulmala et al., 1998; Mäkelä et al., 1997), making them one of the longest continuous measurements of aerosol particle number and size distributions in the subarctic (Ruuskanen et al., 2003). These long-term measurements show that aerosol particles regularly form and grow from very small sizes ( $<8 \mathrm{~nm}$ diameter), with the highest particle frequency observed in the spring, between March and May (Dal Maso et al., 2007; Vehkamäki et al., 2004). It is suggested that spring promotes new particle formation (NPF) due to the awakening of biological processes after the winter. At SMEAR I, the snow only melts away in May-June; thus, many biological processes (photosynthesis) activate while the snow is still deep. This makes the Arctic spring a very complex environment for atmospheric chemistry, with possible emission sources from melting snow, ice, meltwater, vegetation and transport from other areas. At SMEAR I, most of the observed NPF events are either connected to clean air arriving from the northern sector (originating from the Arctic Ocean and transported over the boreal forest; Dal Maso et al., 2007) or to polluted air masses from the eastern sector (Kyrö et al., 2014; Sipilä et al., 2021). Annually, around 3060 NPF events are recorded at SMEAR I; half of these events could be initiated by anthropogenic air pollutants from the Kola Peninsula (Kyrö et al., 2014; Pirjola et al., 1998; Sipilä et al., 2021), inferring that half of the events are associated with natural sources. The trend in NPF occurrence in the Värriö reserve is decreasing, as the anthropogenic sulfur dioxide emissions in Russia are decreasing (Kyrö et al., 2014).

The formation and growth of new particles at SMEAR I usually occur during daylight, highlighting the importance of photochemical activities. However, unlike most other locations, NPF is also observed during nighttime or polar night at this site (Kyrö et al., 2014; Vehkamäki et al., 2004). The formation and growth processes of aerosols do not seem to be correlated with each other at SMEAR I (Vehkamäki et al., 2004). Earlier literature has reported that the formation rate $(\mathrm{J})$ has no clear seasonal trend, whereas the growth rates (GR) of small particles clearly peak during summer (Ruuskanen et al., 2007). This indicates that different chemistry drives the initial cluster formation and the subsequent growth processes. From the observed nucleation rates, it has been proposed that NPF at SMEAR I could be due to sulfuric acid-ammonia (-water) nucleation (Napari et al., 2002), likely dominated by the ion-induced channel, at least during winter months (Sipilä et al., 2021). Kyrö et al. (2014) concluded that $20 \%-50 \%$ of the condensational growth can also be explained by sulfuric acid (SA) in the Värriö reserve. Other studies have speculated about the possibility of different organic compounds participating in NPF in the subarctic. Tunved et al. (2006) studied the air masses arriving at SMEAR I and concluded that the aerosol mass increased linearly with the time that the air masses traveled over land. The concentration of condensing gases over the boreal forest was concluded to be high and most likely consisting mainly of oxidation products of terpenes (VOCs) that are emitted by the forest. At the SMEAR II station in Hyytiälä, approximately $700 \mathrm{~km}$ southwest of Värriö, oxidized organics mostly explain the growth of newly formed particles (Bianchi et al., 2017; Ehn et al., 2014). However, direct measurements of the aerosol-forming and aerosol-growing vapor species are still lacking from SMEAR I except during wintertime (without biogenic activity), during which time SA has been shown to be primarily responsible for formation and growth (Sipilä et al., 2021). In the Värriö reserve, the role of NPF is critical in the formation of cloud condensation nuclei (CCN), as measurements show that the number of $\mathrm{CCN}$ can increase by up to $800 \%$ as a result of NPF (Kerminen et al., 2012). At other locations in the boreal forest and the Arctic, some measurements have shed light on the possible chemical components that could be forming particles in the Värriö reserve. Currently, the closest continuous measurements with a nitrate-based chemical ionization atmospheric pressure interface time-of-flight (CI-APi-TOF) mass spectrometer are conducted in Hyytiälä at the SMEAR II station (Jokinen et 
al., 2012, 2017; Kulmala et al., 2013). In Hyytiälä, there is direct evidence of the key role of the photochemical production of SA and highly oxygenated organic molecules (HOMs) in maintaining atmospheric NPF (Bianchi et al., 2017; Ehn et al., 2014; Jokinen et al., 2017; Kulmala et al., 2013).

Other chemical composition measurements of aerosol precursors have only been conducted in a few locations in the High Arctic and over the Arctic Ocean (Baccarini et al., 2020; Beck et al., 2021; He et al., 2021; Sipilä et al., 2016). These studies have shown that the marginal ice zone and the coast of the Arctic Ocean are a source of atmospheric iodic acid (IA) in the Arctic that efficiently forms new particles. SA and methane sulfonic acid (MSA) concentrations have also been reported (Beck et al., 2021), but they were much lower in concentration than IA (Baccarini et al., 2020). However, the chemistry behind NPF is not that simple, even in the pristine Arctic air. The clean air above the Arctic Ocean is abundant in dimethyl sulfide (DMS), emitted by phytoplankton, that rapidly oxidizes into SA and MSA on sunny days and, consequently, forms CCN (Charlson et al., 1987; Park et al., 2018). Beck et al. (2021) reported that SA and MSA contribute to the formation of secondary aerosol on Svalbard in the Arctic Ocean. They also observed that these compounds formed particles large enough to contribute to $\mathrm{CCN}$ to some extent. This is supported by measurements of the aerosol chemical composition from the Arctic that commonly report MSA in particulate matter (Dall Osto et al., 2018; Kerminen et al., 1997). According to Beck et al. (2021), initial aerosol formation in the High Arctic occurs via the ion-induced nucleation of SA and ammonia, and subsequent growth is mainly due to SA and MSA condensation during springtime and HOMs during summertime. By contrast, in an ice-covered region around Villum, Greenland, Beck et al. (2021) observed NPF driven by IA, but the particles remained small and did not grow to $\mathrm{CCN}$ sizes due to an insufficient concentration of condensing vapors. As the Arctic CCN number concentrations are low in general, the formation of new particles is a very sensitive process affecting the composition of the aerosol population and $\mathrm{CCN}$ numbers in the area.

In this article, we present the measurements of aerosol precursor molecules from the continental SMEAR I station, $\sim 150 \mathrm{~km}$ north of the Arctic Circle and $\sim 150 \mathrm{~km}$ from the Arctic Ocean. We measured SA, MSA, IA and HOM concentrations with an SA-calibrated CI-APi-TOF mass spectrometer (Jokinen et al., 2012; Kürten et al., 2012) to determine their levels in the subarctic boreal forest and to understand whether these species are connected with the aerosol formation process in the area.

\section{Methods, measurement site and instrumentation}

The core of this work involves measurements of gas-phase aerosol precursors. We use a nitrate-based chemical ioniza- tion atmospheric pressure interface time-of-flight (CI-APiTOF) mass spectrometer that has been operational at the SMEAR I station $\left(67^{\circ} 45^{\prime} 19^{\prime \prime} \mathrm{N}, 29^{\circ} 36^{\prime} 37^{\prime \prime} \mathrm{E}\right)$ in Eastern Lapland since the early spring of 2019. Measurements were done on top of Kotovaara hill (390 m a.s.1.), close to ground level in an air-conditioned small wooden cottage. The cottage is surrounded by $\sim 65$-year-old Scots pine forest. More details about the station can be found in earlier publications (Hari et al., 1994; Kyrö et al., 2014). The mass spectrometric measurements have been designed to start a long-term measurement series of atmospheric aerosol-forming trace gases in Finnish Lapland, and the measurements are ongoing to this day. We measure species such as SA, IA, HOMs and MSA with high time resolution and precision. The measurements are run in eastern European time $($ EET, UTC +2$)$ throughout the year.

We calibrated the CI-APi-TOF twice during the measurement period, and the instrument was run with the same settings for the whole measurement period reported in this paper. We calibrated the instrument using an SA calibrator, as described in Kürten et al. (2012). The respective calibration factors from the two separate calibrations were $7 \times 10^{9}$ and $8 \times 10^{9}$, and we used the average, $7.5 \times 10^{9}$, in our study to calculate the concentrations of all reported compounds. This factor includes the loss parameter due to the $\sim 1 \mathrm{~m}$ long unheated inlet tube $(3 / 4 \mathrm{in}$., approx. $1.9 \mathrm{~cm}$, stainless steel). HOMs and IA were estimated to be charged similarly at the kinetic limit to SA (Ehn et al., 2014; Sipilä et al., 2016), so the calibration factor for these species should be similar; however, the reader should note that the concentration of compounds other than SA can be highly uncertain due to different ionizing efficiencies, sensitivities and other unknown factors. If MSA, IA or HOMs do not ionize at the kinetic limit, these concentrations could be underestimated; thus, the concentrations reported herein should be taken as lower-limit values. The SA, IA and MSA data presented in this study are all the result of high-resolution peak fitting of the CI-APi-TOF, in order to avoid the inaccurate identification of compounds and to separate overlapping peaks. The HOM data are the sum of mass-to-charge ratios from 300 to $400 \mathrm{Th}$, representing the monomer HOM range $\left(\mathrm{C}_{10} \mathrm{com}-\right.$ pound range); 401 to $500 \mathrm{Th}$, representing the slightly larger HOMs $\left(\mathrm{C}_{15}\right.$ compound range); and 501 to $600 \mathrm{Th}$, representing the dimer species $\left(\mathrm{C}_{20}\right.$ compound range). We also give the sum of the abovementioned ranges (from 300 to $600 \mathrm{Th}$ ). However, the goal of this article is not to specify different HOM compounds or to study NPF in mechanistic detail; instead, we wish to give an overview of general seasonal trends and variations in these selected species. Note that, as this is the sum of all of the peaks in the selected mass range, we cannot assure that all of the compounds included are HOMs. However, investigation under laboratory conditions shows that the nitrate-based CI-APi-TOF is highly selective and sensitive towards HOMs with $\mathrm{O}>5$ (Riva et al., 2019 ) and with hydroperoxide (-OOH) functionalities (Hyt- 
tinen et al., 2015). All data obtained from the CI-APi-TOF were analyzed using the tofTools program, described in Junninen et al. (2010), and were averaged over $1 \mathrm{~h}$. The original data time resolution is $5 \mathrm{~s}$. The uncertainty range of the measured concentrations reported in this study is estimated to be $-50 \%$ to $+100 \%$, and the limit of detection (LOD) is $4 \times 10^{4}$ molec. $\mathrm{cm}^{-3}$ (Jokinen et al., 2012).

To classify NPF events recorded during the measurement period, we used data measured by a differential mobility particle sizer (DMPS). Condensation sink was also calculated using the DMPS data. The DMPS instrument and earlier statistics of NPF events in the Värriö reserve have been documented by Dal Maso et al. (2007), Vana et al. (2016) and Vehkamäki et al. (2004). The NPF events were classified according to Maso et al. (2005). The total aerosol particle number concentration was measured with a condensation particle counter (CPC, TSI 3776) in the size range from 3 to $800 \mathrm{~nm}$. Air ion size distributions were measured with a neutral cluster and air ion spectrometer (NAIS; Kulmala et al., 2007; Manninen et al., 2016; Mirme and Mirme, 2013) that measures negative and positive ions in the size range from 0.8 to $42 \mathrm{~nm}$ in mobility diameter and the total particle size distribution between $\sim 2$ and $42 \mathrm{~nm}$.

\section{Results and discussion}

\subsection{Overview of the whole measurement period}

A time series of the most common aerosol precursor compounds, SA, MSA and IA, and sums of different HOM groups are given in Fig. 1. This figure depicts the whole measurement period from 4 April to 27 October in 2019. Overall, we succeeded in almost interrupted measurement of the whole 7-month period. Only a few short power cuts stopped our measurements during this time. IA data are missing from late July, as the peak could not be separated well enough from overlapping peaks in the spectra during this time. This was due to poor resolution (low signal of $\mathrm{IO}_{3}^{-}$close to another peak) that caused the peak integration to give negative, unreal values; thus, we decided to flag these data out. After late October, the instrument malfunctioned and stopped our measurements. In this particular article, we present data from spring (April-May), summer (June-July-August) and autumn (September-October) 2019. More information on the SMEAR I winter observations is given in Sipilä et al. (2021), who report observations of polar night pollution events from Värriö after the CI-APi-TOF was fixed.

In Fig. 2, we show some of the most interesting environmental and meteorological parameters that influence the atmospheric gas composition during the measurement period: temperature, global radiation and snow depth as well as the ozone, $\mathrm{NO}_{x}$ and $\mathrm{SO}_{2}$ mixing ratios. There are some special features in 2019: the summer had two heat waves during which the air temperature rose up to $29.2^{\circ} \mathrm{C}$ in early June and to almost the same values again in late July. These episodes are becoming more common in Lapland due to climate change. These warmer conditions will probably change the emissions of trace gases, including the composition and abundance of aerosol precursors, in the future Arctic environment (Schmale et al., 2021). However, heat wave conditions are likely not favorable for NPF, as the condensation of lowvolatility gases is favored under colder conditions (via the vapor pressure decrease due to lower temperatures), but they may affect the oxidation chemistry of VOCs by promoting dimer formation.

Figure 2 also shows that the snow-covered period ended in late May in 2019, and snow started to accumulate again in mid-October. Solar radiation (Fig. 2a) is intense in the Värriö reserve during springtime and causes favorable photooxidation conditions, effectively removing air pollutants and trace gases from the atmosphere. Photochemical activity in the presence of $\mathrm{NO}_{x}$ (Fig. 2e) produces ozone in springtime, and this is visible in very high ozone mixing ratios at the site (Fig. 2d). Median ozone mixing ratios were around $55 \mathrm{ppbv}$ in April and decreased to $\sim 30 \mathrm{ppbv}$ in the late summer and autumn. The spring ozone mixing ratio in 2019 was significantly higher than the previous reports from 1992 to 2001, during which time monthly mean values of ozone varied between 25 and 40 ppbv (Ruuskanen et al., 2003).

The springtime diurnal solar cycle is clearly visible in all of the studied compounds. All measured aerosol precursor compounds are abundant, even during the period when snow covers the ground in the spring. The HOM concentrations follow increasing solar radiation and rising temperature. MSA has a stronger diurnal cycle before the snowmelt than after it. This may be due to rain and cloudy conditions that are more common in the summer. The seasonal variation in SA and IA is not as strong as that of HOMs and MSA. The aerosol precursor concentrations are discussed in more detail in the following sections.

\subsection{Seasonal and monthly variation in SA, MSA, IA and HOM concentrations}

In Fig. 3, we present the diurnal variation in aerosol precursor (SA, MSA, IA and highly oxygenated molecules) concentrations separately for different seasons as well as the solar radiation and the total aerosol number concentrations. Strong seasonality is most evident in the SA and HOM concentrations. SA is at its highest in the spring, decreasing toward summer and autumn, whereas HOMs reach their maximum in the summer. We detect an increase in the total aerosol number concentration for spring evenings, which is likely due to more frequent NPF events taking place at SMEAR I. The increase in HOMs in summer at SMEAR I is linked to the increased VOC emissions from vegetation that oxidize into HOMs via ozonolysis (Ehn et al., 2014) and OHradical reactions (Berndt et al., 2016; Jokinen et al., 2014, 2017; Wang et al., 2018). The lowest overall aerosol precursor concentrations and aerosol number concentrations were 

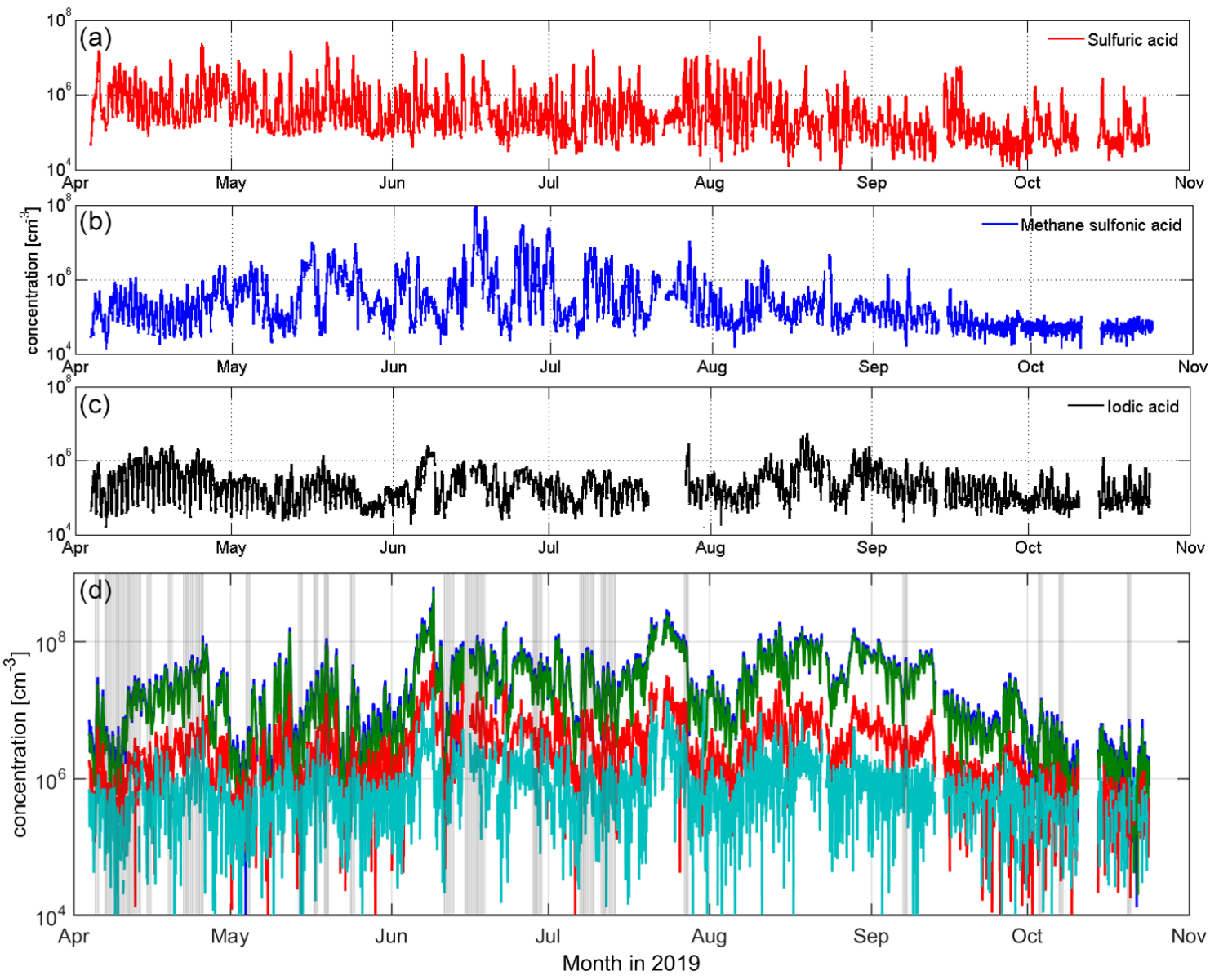

Figure 1. Overview of sulfuric acid (a), methane sulfonic acid (b), iodic acid (c) and HOM (d) concentrations at SMEAR I from April to October 2019. NPF days are depicted using gray shading in panel (d). All of the data in panels (a-c) result from high-resolution peak fitting. $\mathrm{HOM}$ data are sums of certain mass ranges: from 300 to $400 \mathrm{Th}$ in green, representing $\mathrm{C}_{10}$ or HOM monomer compounds; from 401 to $500 \mathrm{Th}$ in red, representing $\mathrm{C}_{15}$ compounds; and from 501 to $600 \mathrm{Th}$ in light blue, representing $\mathrm{C}_{20}$ or HOM dimer compounds. The sum of HOM (darker blue) is the sum of the aforementioned mass ranges. The sum of HOMs is approximately 1 order of magnitude higher than the SA, MSA or IA concentrations during this measurement period.

detected during autumn (winter data were missing in this study; the reader is referred to Sipilä et al., 2021, for wintertime observations made promptly after the period reported here). MSA shows very similar concentrations during spring and summer before dropping down to close to the limit of detection for autumn. IA acts very differently from the other compounds: we observe IA to have a similar level of concentration throughout the measurement period, and it seems that the concentration reaches a steady state during daylight hours. This daytime maximum stays at the same level for about $5 \mathrm{~h}$ longer during spring than in the autumn; the day length becoming shorter towards autumn explains this behavior. The maximum hourly median concentrations for the measured compounds are $\sim 2 \times 10^{6} \mathrm{~cm}^{-3}$ for SA (spring), $\sim 5 \times 10^{5} \mathrm{~cm}^{-3}$ for MSA (summer), $\sim 3 \times 10^{5} \mathrm{~cm}^{-3}$ for IA (all seasons) and $\sim 5 \times 10^{7} \mathrm{~cm}^{-3}$ for the sum of HOMs (summer, mass range from 300 to $600 \mathrm{Th}$ ).
We can compare these numbers to SMEAR II long-term (5-year median concentration) observations, where the median peak SA concentrations are $\sim 1.5 \times 10^{6}, \sim 1 \times 10^{6}$ and $\sim 3 \times 10^{5} \mathrm{~cm}^{-3}$ for spring, summer and autumn, respectively (Sulo et al., 2021). These measured concentrations are very similar to SMEAR I observations, except there are slightly higher summer and autumn SA concentrations at SMEAR II. However, it should be noted that the springtime measurements from SMEAR I do not include March data, which makes the springtime comparison somewhat uncertain. The SMEAR II data set that includes March data cannot be expected to be perfectly comparable with our data. However, as reported by Sipilä et al. (2021), the March data from the following year seem to show very similar concentration levels to those that we report in here for spring (a maximum of $\sim 2 \times 10^{6} \mathrm{~cm}^{-3}$, and daily averages peak at around $0.5 \times 10^{6} \mathrm{~cm}^{-3}$ ). We expect that the SA concentrations are only marginally affected by the lack of March data but also 

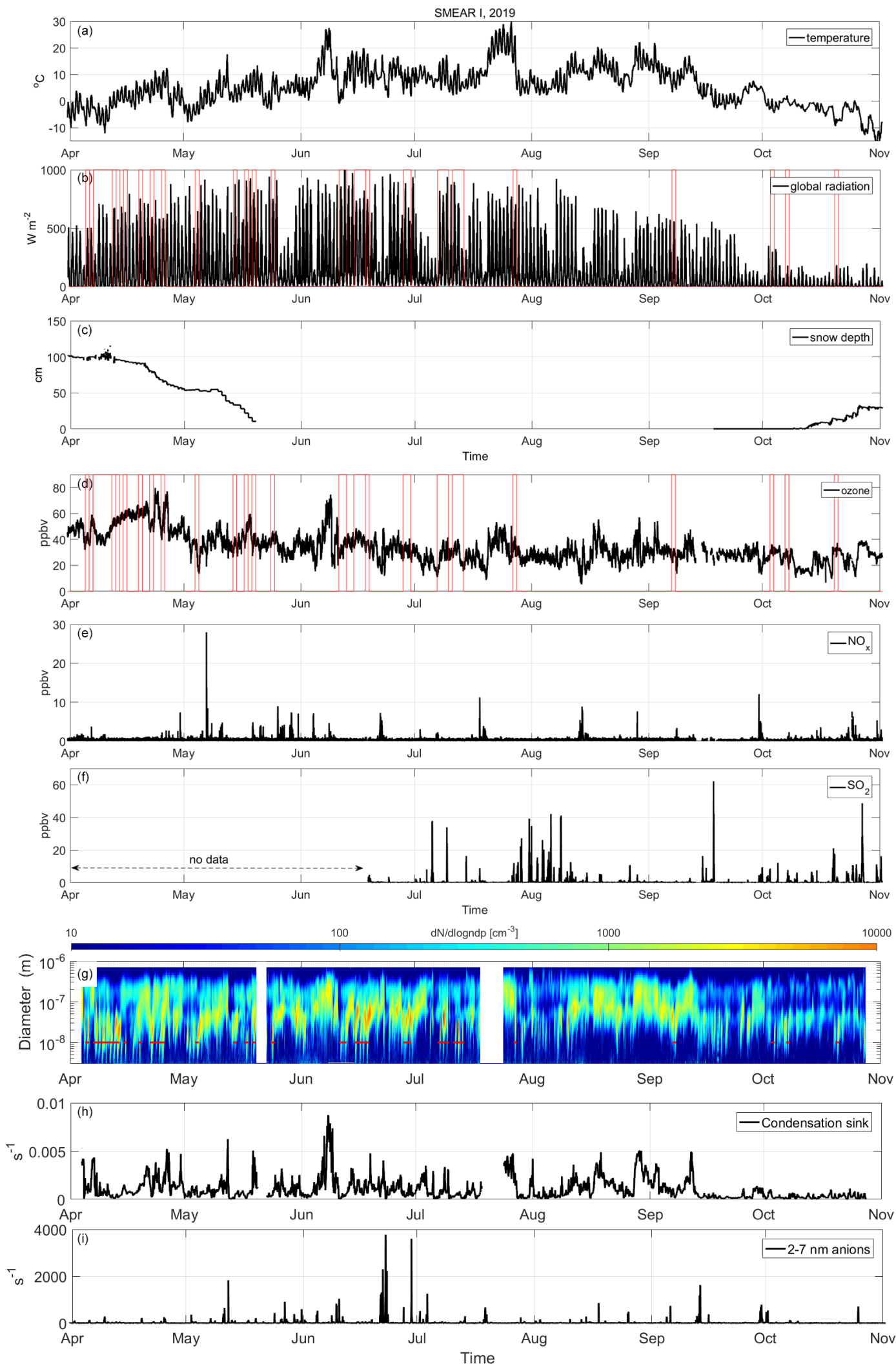

Figure 2. Observations of temperature (a); global radiation (b); snow depth (c); ozone (d), $\mathrm{NO}_{x}(\mathbf{e})$ and $\mathrm{SO}_{2}$ (f) mixing ratios; number size distribution (g); condensation sink (h); and the concentration of 2-7 nm anions (i) at $\mathrm{SMEAR}$ I during the measurement period. $\mathrm{SO}_{2}$ data are missing until mid-June due to an instrument malfunction. NPF event times are depicted in red in panels (b), (d) and (g). 
that the level of HOMs, MSA or IA could be affected more due to very different meteorological conditions between the stations in springtime (SMEAR II is $\sim 700 \mathrm{~km}$ further south than SMEAR I). There is also a difference in the timing of the peak SA concentration in the summer. At SMEAR I, the peak concentration is reached at noon (12:00 EET), whereas it can be found some hours earlier (at around 8:00 EET in the morning) at SMEAR II (Sulo et al., 2021). In the case of HOMs, we cannot directly compare the concentrations measured in this work to those from Sulo et al. (2021), as they calculated the sum of HOMs differently, only taking the most abundant signals into account and separating nitrate and nonnitrate HOMs. However, we take the liberty of comparing diurnal and seasonal variations. At both SMEAR I and II, observations show the highest HOM concentrations during summer, whereas the autumn concentrations are 1 order of magnitude lower. The comparison between these sites reveals different diurnal variations in HOMs. At SMEAR I, HOMs have a maximum at around noon, spanning to the afternoon (Fig. 3), whereas HOMs have two maxima at SMEAR II, one at noon and another one in the early evening; the latter of two maxima at SMEAR II is connected to non-nitrate monomer and dimer HOMs and nitrate dimer HOMs. At SMEAR I, the lack of an evening maximum could indicate that HOM dimer formation is less dominant at this site than at SMEAR II. This may be caused by lower air temperatures or by the different diurnal cycle of oxidants due to longer hours of solar radiation north of the Arctic Circle.

When analyzing the monthly aerosol precursor profiles in Fig. 4, we observe that the springtime atmosphere is abundant in SA and IA, with the highest median concentrations of these species in April. MSA and HOM concentrations peak in June. The MSA behavior is likely connected to the algae blooms in the Arctic Ocean, which peak around midsummer. The marine emissions of DMS oxidize to sulfur dioxide, SA and MSA in the atmosphere (e.g., Park et al., 2018). However, SA has more sources, as $\mathrm{SO}_{2}$ also has anthropogenic sources. At SMEAR I, we cannot distinguish these sources precisely (this is discussed further in Sect. 3.3.). It is notable that the peak concentration of MSA is earlier in the day in April, around noon (12:00 EET), than it is later in the year, when the peak concentration is reached in the late afternoon (from 13:00 to 18:00 EET). There are no previous MSA concentration reports from the SMEAR stations, but some gasphase MSA results from Antarctica show a maximum concentrations of between $1 \times 10^{5}$ and $1 \times 10^{7} \mathrm{~cm}^{-3}$ (Jokinen et al., 2018; Mauldin et al., 2004, 2010). In the Arctic, a measurement series taken over approximately 6 months in Villum in Greenland shows MSA concentrations $<10^{6} \mathrm{~cm}^{-3}$ (March-September) and from $10^{5} \mathrm{~cm}^{-3}$ to $10^{7} \mathrm{~cm}^{-3}$, with the highest concentrations in June in Ny-Ålesund (Beck et al., 2021). Our measurements from the SMEAR I site fall between these extremes.

These are also the first reported results of IA measurements from SMEAR I, and they represent a continental loca- tion, with the White Sea coast being $\sim 130 \mathrm{~km}$ to the southeast and the Barents Sea being $\sim 230 \mathrm{~km}$ to the northeast of the measurement location. IA, iodine and iodine oxoacid emissions are commonly connected with coastal or marine environments (Baccarini et al., 2020; McFiggans et al., 2010; O'dowd et al., 2002; Sipilä et al., 2016; Yu et al., 2019) due to the fact that the ocean surface is a major source of iodine (Carpenter et al., 2013). While it is not precisely known how IA forms in the gas phase, its formation requires the oxidation of the initial precursors $\left(\mathrm{IO}_{x}\right.$ species) by ozone, and the last steps of its formation are potentially driven by reaction with OH (Chameides and Davis, 1980).

Compared with the other precursor compounds, IA has the most stable concentration between seasons, with a long increasing period in April during the snow-melting season. This is likely due to the simultaneously increasing ozone mixing ratios (Fig. 2d) and solar radiation. In contrast with measurements from the Arctic Ocean (Baccarini et al., 2020), we did not observe a clear increase in the IA concentration in the autumn due to freezing. We find that September had only marginally higher concentrations compared with August or July (Fig. 4). Winter measurements would be necessary to estimate the effect of freezing on the concentration of IA.

The source of IA at a continental site like SMEAR I is an interesting subject to speculate about. The observed $\mathrm{HIO}_{3}$ peak in April could indicate an influence from air masses exposed to the Arctic marine environment. The increasing temperatures in the spring induce a higher activity of phytoplankton in the nearby Barents Sea and Norwegian Sea, which remain ice-free even during the winter, and could result in the higher emission of precursors of IA (Lai et al., 2011). Higher temperatures would also result in more efficient advection, which would more quickly transport species from emission points to SMEAR I. The calculated back trajectories support the idea that iodine-rich air masses arrive at SMEAR I from the west or northwest (this is discussed in more detail in Sect. 3.3 and Fig. 10). This would cause one to hypothesize that long-range transport is the source of IA at SMEAR I. On the contrary, the strong diurnal variation in the IA concentration, seen as a 1 order of magnitude difference between noon and midnight, suggests fast on-site chemistry, which is not consistent with the long-range transport of IA and instead points to a precursor species such as $\mathrm{CH}_{3} \mathrm{I}$ (Bell et al., 2002). Moreover, the IA lifetime against condensational loss is expected to be short with the condensation sink at the site (Fig. 2h), in the range of $\sim 15 \mathrm{~min}$; this suggests that $\mathrm{HIO}_{3}$ is formed close to or at the measurement site. Land vegetation is also a source of methyl iodide $\left(\mathrm{CH}_{3} \mathrm{I}\right)$, which could be the source of IA at SMEAR I at least during summer (Sive et al., 2007).

Most interestingly, we seem to have an emission source of iodine during all seasons. There are no reports on iodine emissions from continental snow, but we hypothesize that one possible source of iodine at SMEAR I during spring is the snowpack. This is possible due to the deposition of 

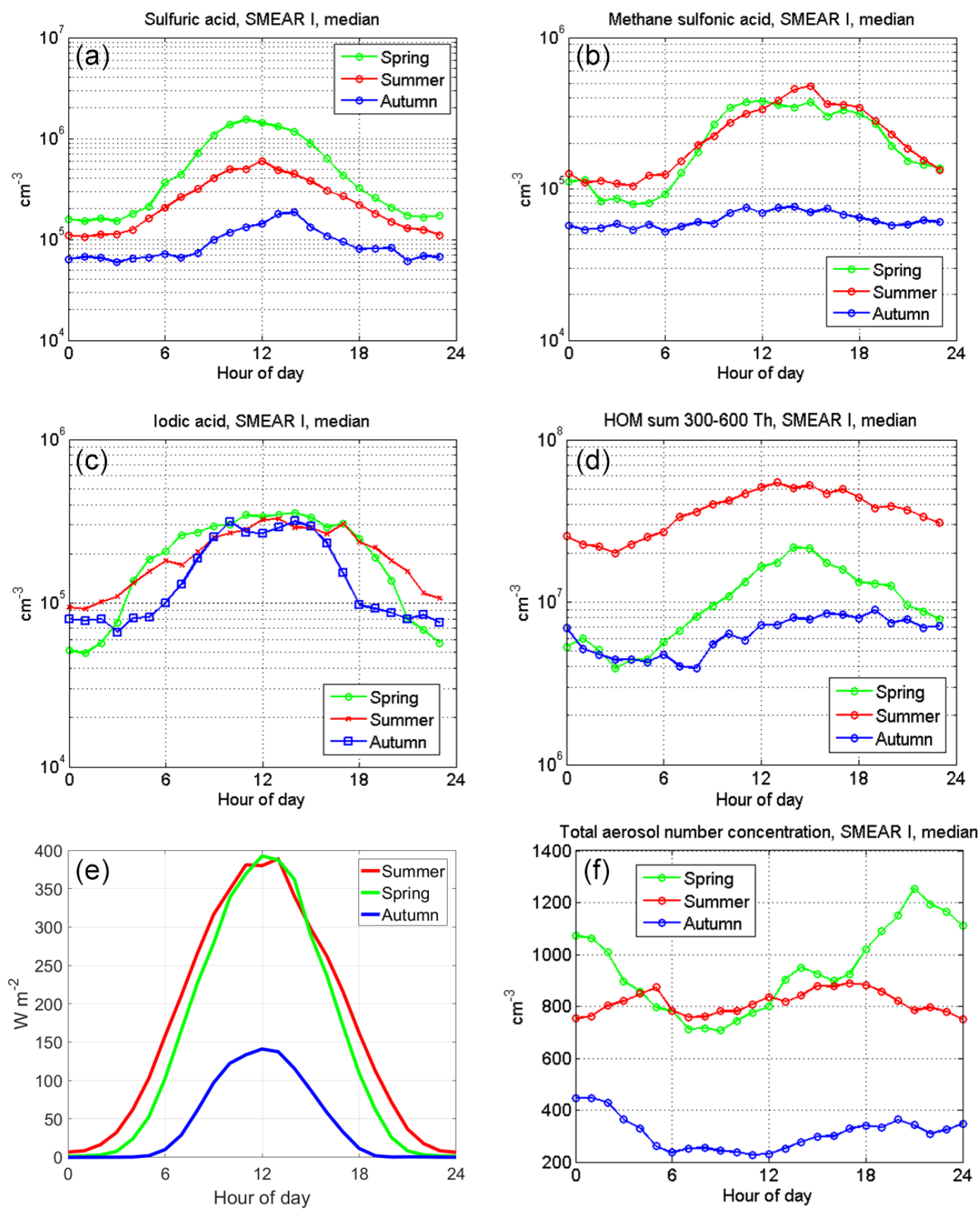

Figure 3. The diurnal variation in aerosol precursor gas median concentrations in different seasons for (a) sulfuric acid, (b) methane sulfonic acid, (c) iodic acid and (d) the sum of HOMs in the 300 to 600 Th mass range. Panel (e) depicts the seasonal variation in global radiation, and panel (f) shows the seasonal variation in the total aerosol number concentration $\left(N_{\text {tot }}\right)$. The small (false) offset $\left(6-7 \mathrm{~W} \mathrm{~m}^{-2}\right)$ in the summer data is due to $24 \mathrm{~h}$ sunlight conditions in the Värriö reserve.

sea salts on snow, particularly during dark periods, that activate during the spring and are re-emitted to the atmosphere through heterogeneous photochemistry of iodide and iodate ions (Raso et al., 2017; Spolaor et al., 2019). There are also possible forest emissions of iodinated organics, similar to the New England growing season (Raso et al., 2017), that might be enhanced by higher temperature or high ozone concentra- tions. This type of emission of iodinated gases or the implications of this type of emission have not been studied before, but these observations might direct research into emission studies at SMEAR I, as our findings indicate that vegetation could be an emission source of iodine.

The sum of HOMs at SMEAR I reaches up to a median concentration of $\sim 5 \times 10^{7} \mathrm{~cm}^{-3}$ in the summer. This is about 

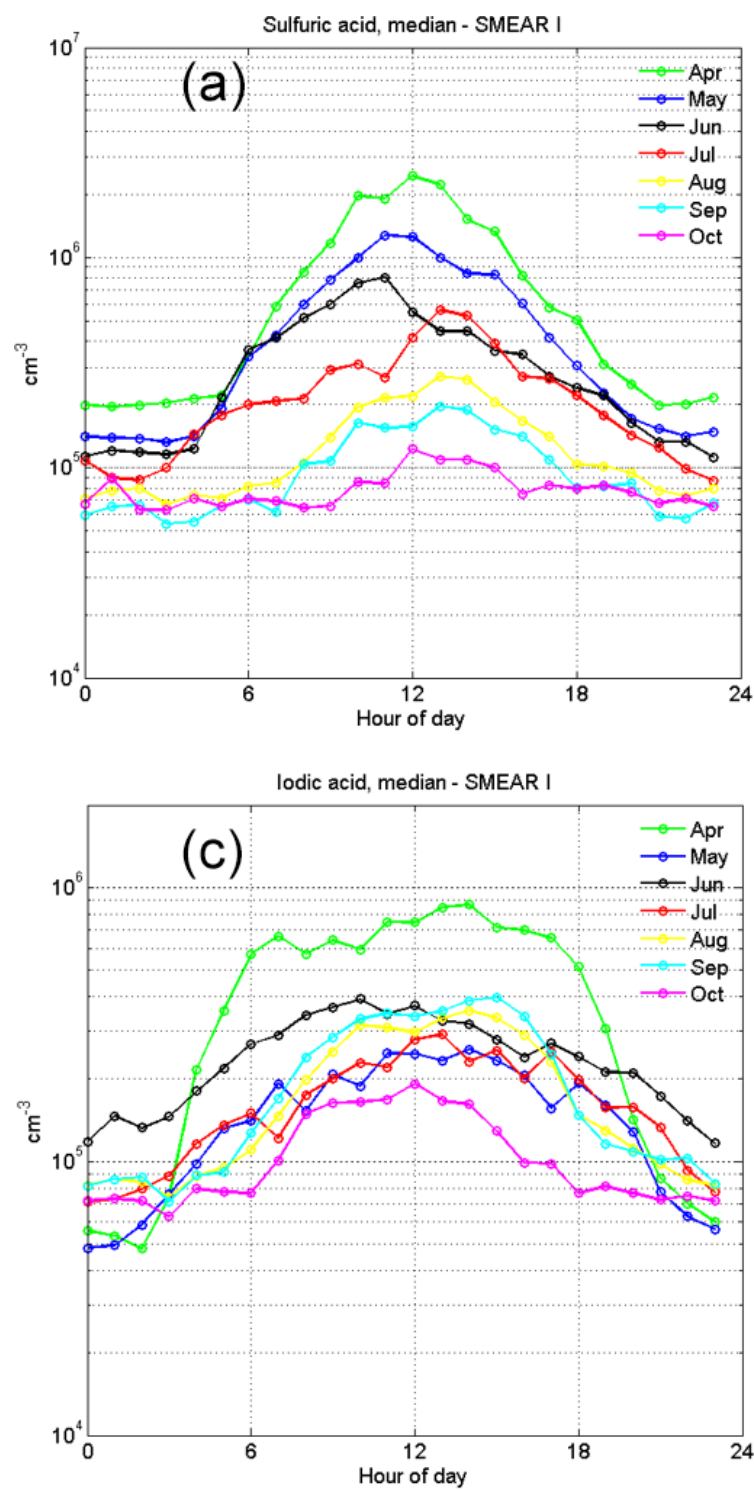
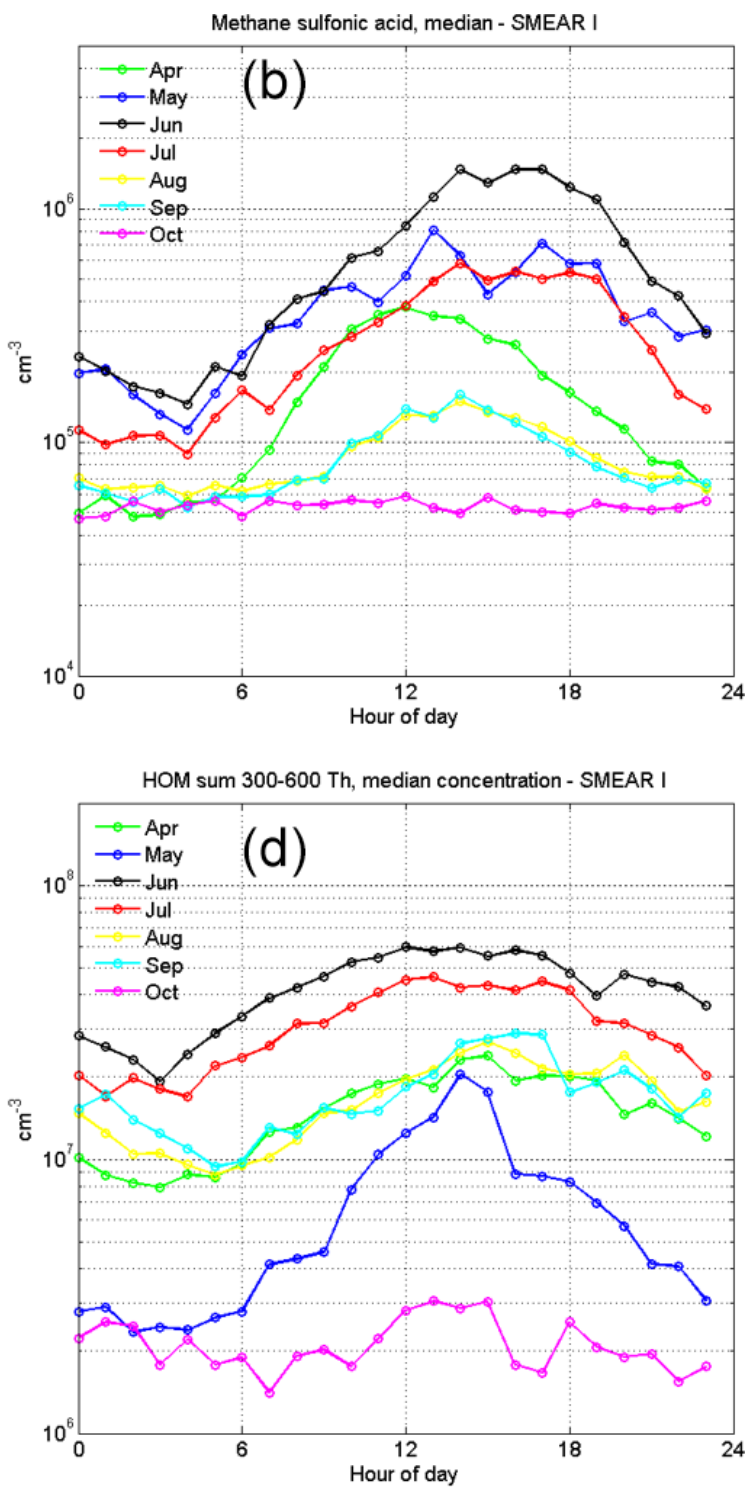

Figure 4. Monthly median concentrations of (a) sulfuric acid, (b) methane sulfonic acid, (c) iodic acid and (d) the sum of HOMs in the 300 to $600 \mathrm{Th}$ mass range.

1 order of magnitude lower than the concentrations reported from the SMEAR II station in Hyytiälä (Yan et al., 2016), about $700 \mathrm{~km}$ south, where HOM concentrations reach a maximum of $\sim 6 \times 10^{8} \mathrm{~cm}^{-3}$ during daytime in spring. It is striking how well the HOM concentrations follow the air temperature (Fig. 5), but this seems to level off above circa $18^{\circ} \mathrm{C}$. Due to this strong temperature dependency, we can speculate that most VOCs emitted by vegetation close to Värriö could be monoterpenes. This is supported by emission rate measurements of VOCs which show that $60 \%-$ $85 \%$ of VOC emissions in northern Finland are accounted for by $\alpha$ - and $\beta$-pinene (Tarvainen et al., 2005). However, sesquiterpene emissions from nearby wetlands could contribute to HOMs, as their emissions are also temperature de- pendent and can originate from boreal wetlands (Hellén et al., 2020; Seco et al., 2020). As HOMs are oxidation products of VOCs, it is evident that the HOM concentration will increase at SMEAR I in the future with increasing VOC emissions, including isoprene, monoterpenes and sesquiterpenes, due to temperature increases (Ghirardo et al., 2020; Tiiva et al., 2008; Valolahti et al., 2015).

\subsection{New particle formation events}

During the measurement period from 4 April to 27 October 2019, we observed 36 regional NPF events in total, and our CI-APi-TOF data cover 33 of these NPF days. During the same period, we observed 75 non-event days - days without clear signs of particle formation (Maso et al., 2005). The rest 

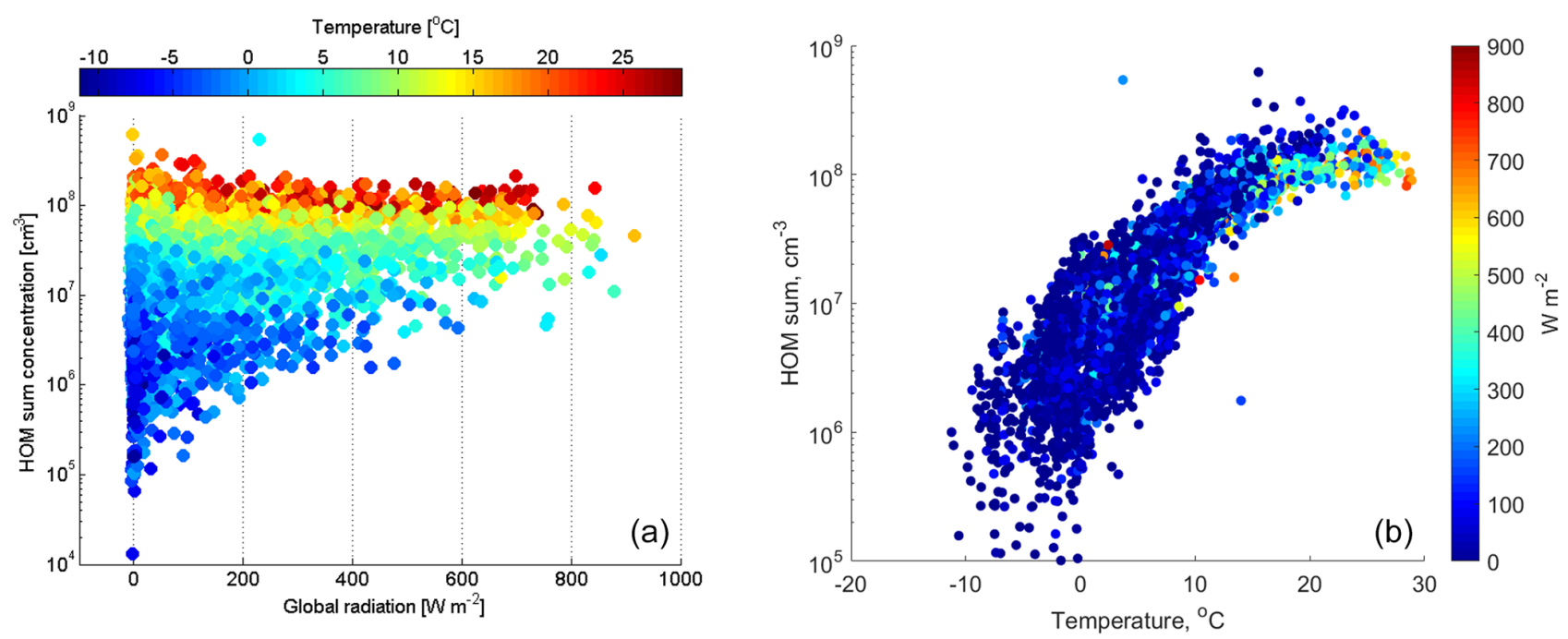

Figure 5. The HOM concentration $\left(\mathrm{cm}^{-3}\right.$ ) measured at SMEAR I (sum of the mass range from 300 to $600 \mathrm{Th}$ ) as a function of (a) global radiation $\left(\mathrm{W} \mathrm{m}^{-2}\right)$ and $(\mathbf{b})$ temperature $\left({ }^{\circ} \mathrm{C}\right)$. The color bar represents air temperature in panel (a) and global radiation in panel (b). The plot includes all data measured from April to October 2019.

of the days during our measurement period were defined as undefined, bad data or partly bad data days, and these were excluded from our analysis. In this section, we focus on trace gases, meteorological parameters and detected aerosol precursor gases during NPF days and compare them to nonevent days.

We plot the median average number size distribution of aerosol particles (from 3 to $800 \mathrm{~nm}$ ) on NPF and non-event days in Fig. 6, and the total number concentration and the 2$7 \mathrm{~nm}$ air ion concentrations are shown in Fig. 7. The whole measurement period is given in Fig. 2. In Fig. 6, we see a distinct "banana" plot for the NPF event days, with small $(<10 \mathrm{~nm})$ particles forming and growing with time. The DMPS data are plotted from 2.82 to $708 \mathrm{~nm}$, but the reader should note that the channels below $\sim 5 \mathrm{~nm}$ have much larger uncertainties than those above. The median event start time is located at around noon, and the growth of particles continues steadily until midnight. However, when looking at individual days, there is a large variation in the start times of particle formation, with some events starting early in the morning or even at night, whereas some start in the late afternoon. Nonevent days show very few particles in the $<10 \mathrm{~nm}$ size bins.

The total number of particles measured at the site during NPF events rises up to $\sim 2400 \mathrm{~cm}^{-3}$, reaching a maximum concentration at $\sim 17: 00$ EET. This shows that NPF is an important source of aerosol particles in the Värriö reserve, as has previously been reported (Vehkamäki et al., 2004). Non-event days clearly have lower particle concentrations throughout the day, staying lower than $1000 \mathrm{~cm}^{-3}$ on average. The measured $2-7 \mathrm{~nm}$ anion concentrations also remain very low during non-event days. As intermediate ions mainly form during NPF, their concentrations are used as an indicator of NPF events in boreal environments (Leino et al., 2016).
On NPF days, we see a peak in the anion concentration at noon, with the concentration being about 6 times higher than during non-event days. This indicates that negative ions may play a role in SMEAR I particle formation events.

Figure 8 shows the differences in temperature, relative humidity $(\mathrm{RH})$, global radiation and ozone mixing ratios between NPF event days (in red) and non-event days (black). In the Värriö reserve, NPF events preferably occur under relatively low-temperature $\left(1-8^{\circ} \mathrm{C}\right)$ conditions, with a fast temperature increase in the early morning hours as well as lower and decreasing RH (dropping from $90 \%$ to $~ 55 \%$ ) during NPF days compared with non-event days. NPF days clearly have higher global irradiance values $\left(\sim 450 \mathrm{~m}^{-2}\right.$ vs. $\sim 200 \mathrm{~m}^{-2}$ ) and about $10 \mathrm{ppbv}$ higher ozone concentrations than non-event days. Thus, the meteorological conditions favoring NPF are similar to those at the SMEAR II station in Hyytiälä, where sunny clear-sky days with low RH and a condensation sink along with wind directions from the cleaner northerly sector can be used to forecast NPF events (Nieminen et al., 2014).

Next, we show the concentrations of aerosol precursor compounds during NPF and non-event days in Fig. 9. The SA concentrations closely follow the solar irradiation profile (Fig. 8c). Similarly to the results obtained in the High Arctic (Svalbard), MSA is also elevated during NPF events, especially during summer, and could possibly contribute to aerosol growth (Beck et al., 2021). We observe close to an order of magnitude higher MSA concentrations between the NPF and non-events days, highlighting the dominant role of sulfur species in nucleation and growth in general at this site. In order to attribute the source of sulfur species and IA during the NPF and non-event days, we performed a cluster analysis using a geographical-information-system-based software, 

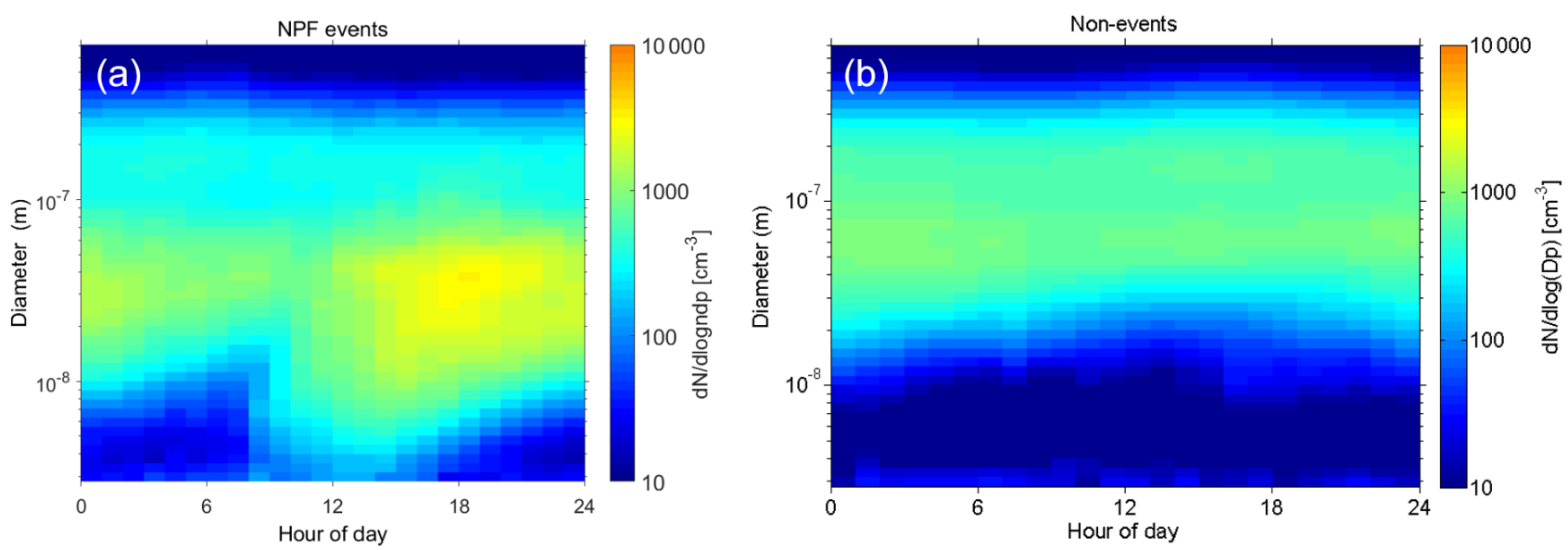

Figure 6. The median number size distribution of all observed NPF events $(n=33)$ and non-events $(n=75)$ during our measurement period. The data were collected with a DMPS, and size bins from 2.82 to $708 \mathrm{~nm}$ are plotted.
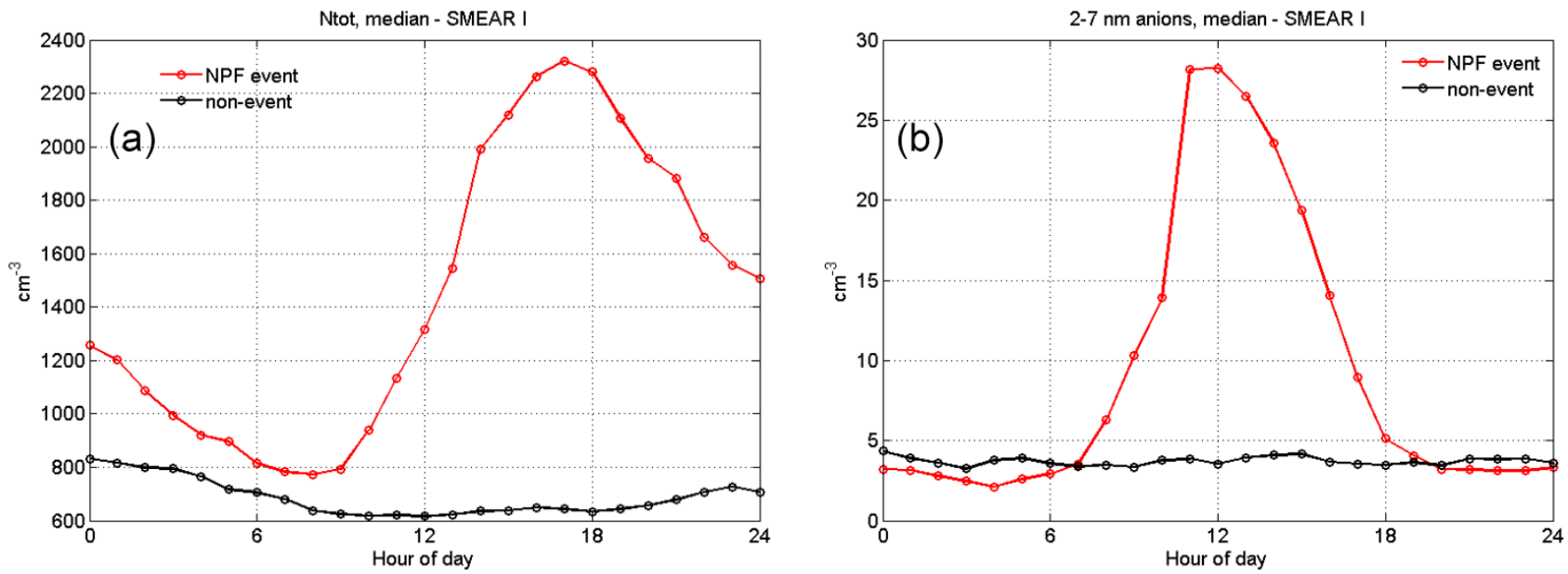

Figure 7. Median (a) total particle concentration $\left(N_{\text {tot }}\right)$ and (b) 2-7 nm negative ion concentrations at SMEAR I during NPF event (red, $n=33$ ) and non-event days (black, $n=75$ ). The total particle number concentration is recorded with a CPC, and air ion concentrations are measured with a NAIS.

TrajStat (Wang et al., 2009). NCEP/NCAR Reanalysis data were used as the meteorological input for the model (Kalnay et al., 1996). The simulations were performed at an arrival height of $250 \mathrm{~m}$ a.g.l., as SMEAR I station is located at similar approximate height ( $390 \mathrm{~m}$ a.s.l.); thus, the simulations could correctly represent the air masses arriving at the station, even during strong temperature inversions (Sipilä et al., 2021).

Higher concentrations of aerosol precursors (SA, MSA and IA) are associated with the air masses that arrive at SMEAR I from the Arctic Ocean (Fig. 10). Cluster analysis of air mass back trajectories arriving at the Värriö reserve during NPF days clearly shows that most NPF events occurred when the air mass had been exposed to marine environments within the preceding $72 \mathrm{~h}$. In our case, these environments were mainly the Norwegian Sea in the west $(58 \%)$ or the Barents $(21 \%)$ and Kara seas $(21 \%)$ in the Arctic
Ocean. This seems relevant to our results, as the marine environment in the north emits large amounts of DMS, which is a precursor for SA and MSA (Levasseur, 2013) as well as iodine species that further oxidize to IA (Baccarini et al., 2020; Sherwen et al., 2016). A fraction of the air masses that are connected to both NPF (21\%) and non-event days (37\%) arrive at SMEAR I from the Kola Peninsula, which is connected to high $\mathrm{SO}_{2}$ emissions, higher particle number concentrations and wintertime NPF events (Sipilä et al., 2021). Most non-event air masses arrive at the Värriö reserve from the southwest (49\%), crossing northern Finland and Sweden.

In addition, from Fig. 9, we observe that we cannot rule out the contribution of IA to NPF at SMEAR I; however the recorded concentrations at SMEAR I would usually not be high enough to initiate NPF (He et al., 2021). Although IA concentrations are slightly higher on NPF days compared with non-event days, the increase in the concentra- 

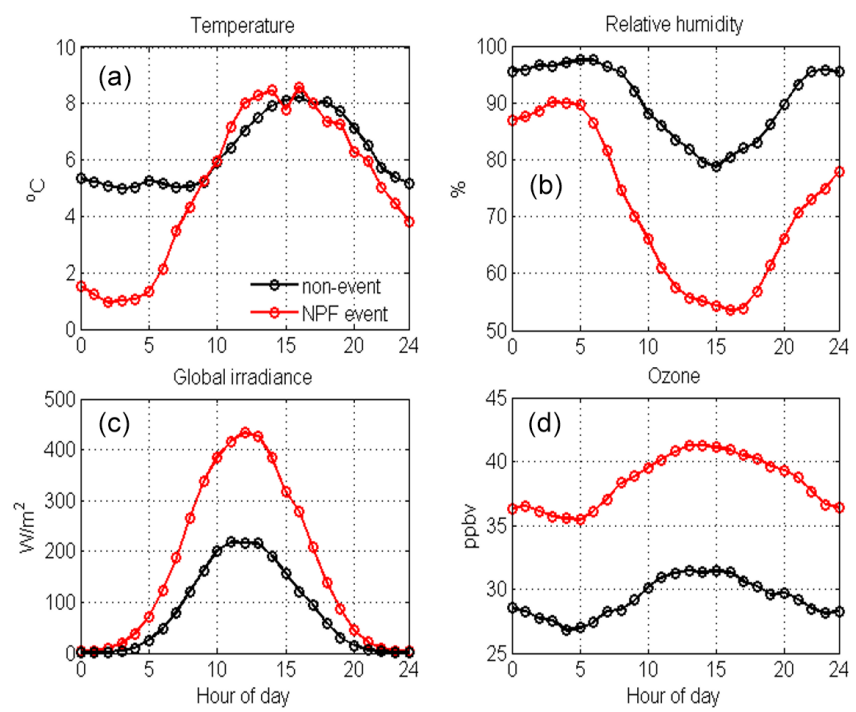

Figure 8. Average (a) temperature $\left({ }^{\circ} \mathrm{C}\right)$, (b) relative humidity $(\%)$, (c) global radiation $\left(\mathrm{W} \mathrm{m}^{-2}\right.$ ) and (d) ozone concentration (ppbv) measured at SMEAR I during NPF event (red, $n=33$ ) and nonevent days (black, $n=75$ ).
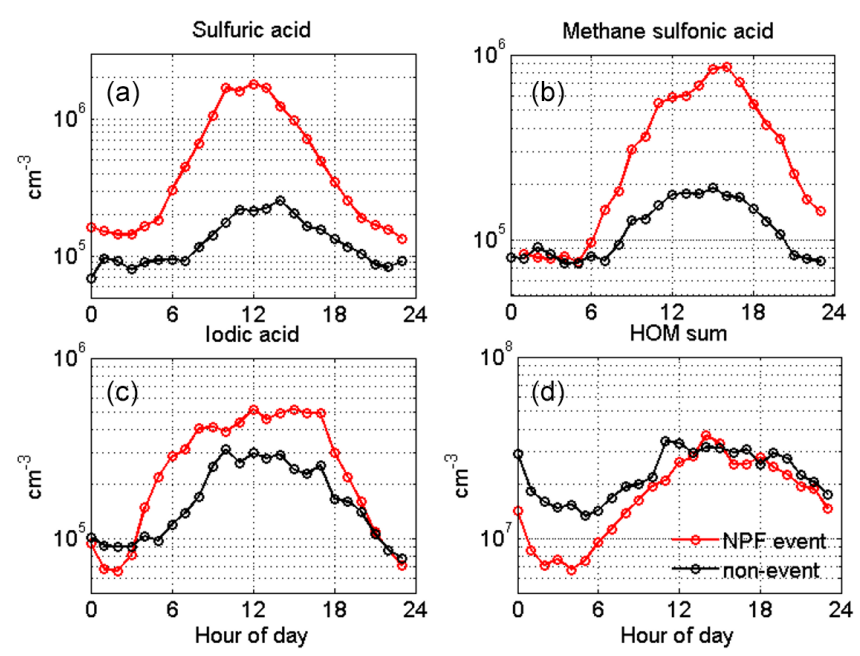

Figure 9. Aerosol precursor gases at SMEAR I during NPF (red, $n=33$ ) and non-event days (black, $n=75$ ). The data are an hourly median average.

tion has already occurred by early morning, clearly before the average event start time. The possible source of IA has been discussed earlier (in Sect. 3.2), and we hypothesize that the source of iodine at SMEAR I could be both (i) longdistance transport from the Arctic Ocean and (ii) local emissions from the snowpack and vegetation. The hypothesis of vegetation-emitted iodine species is supported by the minor difference between NPF event (mostly marine) and nonevent day (mostly continental) concentrations. At SMEAR I, HOMs are the only species that are at a (marginally) lower level on non-event days compared with NPF days, indicating that the total HOM concentration does not determine when NPF events occur. However, this does not exclude the possible participation of certain HOMs in NPF along with sulfur compounds (Lehtipalo et al., 2018) or at later stages of the NPF process, especially during particle growth. Nevertheless, pure biogenic nucleation involving ions and HOMs (Kirkby et al., 2016) does not seem to be a major NPF pathway in the Värriö reserve.

Our measurements do not unveil the detailed mechanism of particle nucleation or growth. We lack the measurements of ambient bases that are needed to stabilize SA clusters under ambient conditions (e.g., Almeida et al., 2013; Jen et al., 2014; Kirkby et al., 2011; Kürten et al., 2014; Myllys et al., 2018). With the given observations comparing NPF days with non-event days, it is likely that most regional NPF events require SA, but the NPF process can involve other compounds as well, especially IA and MSA, which show higher concentrations on NPF days, similar to results reported from Ny-Ålesund (Beck et al., 2021).

\section{Conclusions}

We report $\sim 7$ months of nitrate-based CI-APi-TOF measurements of SA, MSA, IA and HOM from the SMEAR I remote subarctic field station in Finland. The measurements aim to increase our understanding of Arctic aerosol-forming precursors and atmospheric chemistry. The reason for measuring these compounds $\sim 150 \mathrm{~km}$ north of the Arctic Circle is simple: the Arctic is warming at twice the speed of the rest of the planet on average. Lapland is already facing environmental changes such as woody plants dispersing further north and influencing the tundra ecosystem (Aakala et al., 2014; Kemppinen et al., 2021). These changes will, in turn, affect the emissions of aerosol precursor gases, which may have feedback effects on the climate (e.g., Kulmala et al., 2020; Paasonen et al., 2013).

The area surrounding the SMEAR I station has snow cover for almost 8 months of the year. Accumulating snow during the autumn is a good reservoir for chemical species such as halogens, similar to the High Arctic (and Arctic Ocean) environment. The snowpack also acts as a cover for biogenic emissions entering the atmosphere from the ground. Thus, any changes in the temperature and snow cover in subarctic regions will affect the atmospheric chemistry and composition, thereby undeniably changing the way that aerosol particles form as well as their number concentration in this region.

In this study, we report seasonal and monthly variations in SA, MSA, IA and HOM concentrations and find all of these compounds to be abundant in the springtime. SA has a peak concentration in spring, which decreases during the rest of the seasons. We detect high concentrations of MSA and IA that are usually connected to marine and coastal environments, although the Värriö reserve is located $\sim 130 \mathrm{~km}$ 


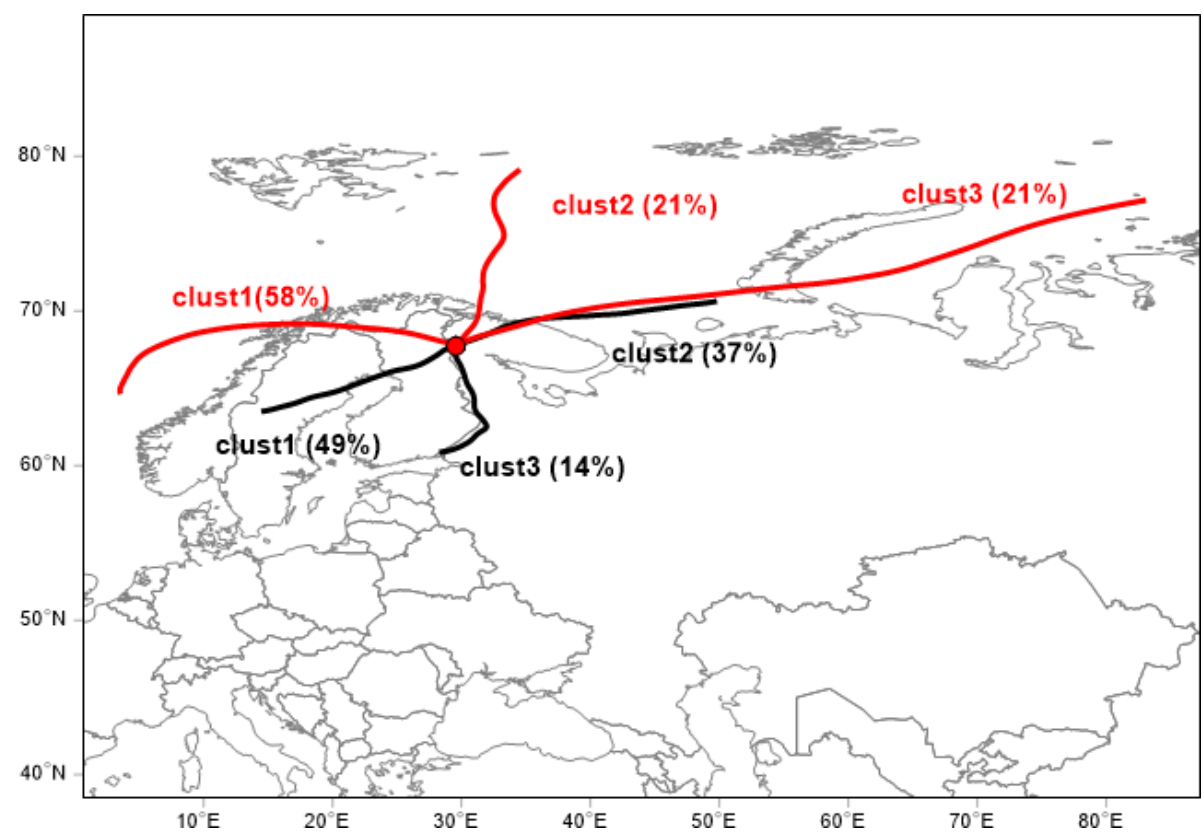

Figure 10. Trajectory cluster analysis of $72 \mathrm{~h}$ back trajectories simulated at an arrival height of $250 \mathrm{~m}$ a.g.l.; NCEP/NCAR Reanalysis data were used as the meteorological input. Red denotes an NPF event, and black denotes a non-NPF period.

from the nearest coast of the White Sea. While MSA is abundant in spring and summer before decreasing to close to the limit of detection in autumn, IA remains at the same concentration throughout the seasons. It seems likely that these two compounds are connected to emissions from phytoplankton or the Arctic ice pack and arrive at SMEAR I via long-range transport routes. In the case of IA, we suggest that the source of iodine emissions is a combination of long-range transport and local emissions from the continental snowpack and vegetation at the site. However, further work is needed to confirm this hypothesis.

We found the most striking correlation between HOM concentrations and the ambient air temperature. The vegetation at SMEAR I is the source of VOCs, even in the snowcovered spring season, and these volatile gases are oxidized into HOMs with different reaction rates depending on the oxidant. In the case of such strong temperature-controlled HOM concentrations, we conclude that HOMs in the mass range of 300-600 Th are most likely products of monoterpene oxidation.

We also studied the abundance of these aerosol precursors separately during NPF and non-event days. We observed that new particles at SMEAR I preferably form under relatively low-temperature $\left(<10^{\circ} \mathrm{C}\right)$ conditions with low $\mathrm{RH}$ that decreases with rising temperature during the day (to a minimum of $\sim 55 \%$ ), a $\sim 10$ ppbv higher ozone mixing ratio than during non-event days, a high SA concentration in the morning and high MSA concentrations in the afternoon. Cluster analysis of air masses shows that NPF usually occurs in marine air masses traveling to the site from a sector reaching from west to north. In summary, these are the first long-term measurements of aerosol-forming precursor from the subarctic region, and these data will help us to develop an understanding of atmospheric chemical processes and aerosol formation in the rapidly changing Arctic.

Data availability. All meteorological parameters, trace gas concentrations and aerosol data were downloaded directly from the SmartSMEAR open-access database: https://smear.avaa.csc.fi/ (Junninen et al., 2009). Mass spectrometric data, event analysis, and condensation sink and anion concentration data are available from Zenodo: https://doi.org/10.5281/zenodo.5879549 (Jokinen et al., 2022).

Author contributions. TJ, MS, TP and MK designed the experiments at SMEAR I, and MS, NS, KN and TL carried them out. IY undertook the NPF event analysis, and RCT calculated the back trajectories. TJ and KL wrote the paper with contributions from all co-authors.

Competing interests. At least one of the (co-)authors is a member of the editorial board of Atmospheric Chemistry and Physics. The peer-review process was guided by an independent editor, and the authors also have no other competing interests to declare.

Disclaimer. Publisher's note: Copernicus Publications remains neutral with regard to jurisdictional claims in published maps and institutional affiliations. 
Acknowledgements. We would like to thank the technical staff in Kumpula and Värriö, who keep the long-term measurements going and who helped with data collection, instrument calibrations, logistics, and data quality control and assurance during the year. We acknowledge the important role that our collaborators had in scientific discussion, and a special thanks goes to Alfonso Saiz-Lopez for IA-related discussion that helped to draft this article. We thank the ACTRIS CiGas-UHEL unit for mass spectrometer calibration support and the tofTools team for data analysis software.

Financial support. This research has been supported by the Academy of Finland via the Center of Excellence in Atmospheric Science (project no. 272041) and by the European Research Council via ATM-GTP 266 (grant no. 742206), GASPARCON (grant no. 714621) and Flagship funding (grant no. 337549). This work also received funding from the Academy of Finland (project nos. 1235656, 296628, 316114, 315203, 307537, 325647, 33397, 334792 and 334514) "Quantifying carbon sink, CarbonSink+ and their interaction with air quality" and an Academy professorship (grant no. 302958). This study was further supported by the European Commission via project iCUPE (Integrative and Comprehensive Understanding on Polar Environments, grant no. 689443), the EMME-CARE project via the European Union's Horizon 2020 Research and Innovation program (under grant agreement no. 856612), the Regional Council of Lapland (Värriön tutkimusaseman huippututkimus hyödyntämään Itä-Lapin elinkeinoelämää, VÄRI, A74190) and the Aatos Erkko Foundation.

Open-access funding was provided by the Helsinki University Library.

Review statement. This paper was edited by Paul Zieger and reviewed by two anonymous referees.

\section{References}

Aakala, T., Hari, P., Dengel, S., Newberry, S. L., Mizunuma, T., and Grace, J.: A prominent stepwise advance of the tree line in north-east Finland, J. Ecol., 102, 1582-1591, https://doi.org/10.1111/1365-2745.12308, 2014.

Ahonen, T., Aalto, P., Rannik, Ü., Kulmala, M., Nilsson, E. D., Palmroth, S., Ylitalo, H., and Hari, P.: Variations and vertical profiles of trace gas and aerosol concentrations and $\mathrm{CO}_{2}$ exchange in eastern Lapland, Atmos. Environ., 31, 3351-3362, https://doi.org/10.1016/S1352-2310(97)00151-9, 1997.

Almeida, J., Schobesberger, S., Kürten, A., Ortega, I. K., Kupiainen-Määttä, O., Praplan, A. P., Adamov, A., Amorim, A., Bianchi, F., Breitenlechner, M., David, A., Dommen, J., Donahue, N. M., Downard, A., Dunne, E., Duplissy, J., Ehrhart, S., Flagan, R. C., Franchin, A., Guida, R., Hakala, J., Hansel, A., Heinritzi, M., Henschel, H., Jokinen, T., Junninen, H., Kajos, M., Kangasluoma, J., Keskinen, H., Kupc, A., Kurtén, T., Kvashin, A. N., Laaksonen, A., Lehtipalo, K., Leiminger, M., Leppä, J., Loukonen, V., Makhmutov, V., Mathot, S., McGrath, M. J., Nieminen, T., Olenius, T., Onnela, A., Petäjä, T., Riccobono, F., Riipinen, I., Rissanen, M., Rondo, L., Ruuskanen, T., Santos, F.
D., Sarnela, N., Schallhart, S., Schnitzhofer, R., Seinfeld, J. H., Simon, M., Sipilä, M., Stozhkov, Y., Stratmann, F., Tomé, A., Tröstl, J., Tsagkogeorgas, G., Vaattovaara, P., Viisanen, Y., Virtanen, A., Vrtala, A., Wagner, P. E., Weingartner, E., Wex, H., Williamson, C., Wimmer, D., Ye, P., Yli-Juuti, T., Carslaw, K. S., Kulmala, M., Curtius, J., Baltensperger, U., Worsnop, D. R., Vehkamäki, H., and Kirkby, J.: Molecular understanding of sulphuric acid-amine particle nucleation in the atmosphere, Nature, 502, 359-363, https://doi.org/10.1038/nature12663, 2013.

Baccarini, A., Karlsson, L., Dommen, J., Duplessis, P., Vüllers, J., Brooks, I. M., Saiz-Lopez, A., Salter, M., Tjernström, M., Baltensperger, U., Zieger, P., and Schmale, J.: Frequent new particle formation over the high Arctic pack ice by enhanced iodine emissions, Nat. Commun., 11, 4924, https://doi.org/10.1038/s41467020-18551-0, 2020.

Beck, L. J., Sarnela, N., Junninen, H., Hoppe, C. J. M., Garmash, O., Bianchi, F., Riva, M., Rose, C., Peräkylä, O., Wimmer, D., Kausiala, O., Jokinen, T., Ahonen, L., Mikkilä, J., Hakala, J., He, X.-C., Kontkanen, J., Wolf, K. K. E., Cappelletti, D., Mazzola, M., Traversi, R., Petroselli, C., Viola, A. P., Vitale, V., Lange, R., Massling, A., Nøjgaard, J. K., Krejci, R., Karlsson, L., Zieger, P., Jang, S., Lee, K., Vakkari, V., Lampilahti, J., Thakur, R. C., Leino, K., Kangasluoma, J., Duplissy, E.-M., Siivola, E., Marbouti, M., Tham, Y. J., Saiz-Lopez, A., Petäjä, T., Ehn, M., Worsnop, D. R., Skov, H., Kulmala, M., Kerminen, V.-M., and Sipilä, M.: Differing Mechanisms of New Particle Formation at Two Arctic Sites, Geophys. Res. Lett., 48, e2020GL091334, https://doi.org/10.1029/2020GL091334, 2021.

Bell, N., Hsu, L., Jacob, D. J., Schultz, M. G., Blake, D. R., Butler, J. H., King, D. B., Lobert, J. M., and Maier-Reimer, E.: Methyl iodide: Atmospheric budget and use as a tracer of marine convection in global models, J. Geophys. Res.-Atmos., 107, ACH 8-1, https://doi.org/10.1029/2001JD001151, 2002.

Berndt, T., Richters, S., Jokinen, T., Hyttinen, N., Kurtén, T., Otkjær, R. V., Kjaergaard, H. G., Stratmann, F., Herrmann, H., Sipilä, M., Kulmala, M., and Ehn, M.: Hydroxyl radical-induced formation of highly oxidized organic compounds, Nat. Commun., 7, 13677, https://doi.org/10.1038/ncomms13677, 2016.

Bianchi, F., Garmash, O., He, X., Yan, C., Iyer, S., Rosendahl, I., Xu, Z., Rissanen, M. P., Riva, M., Taipale, R., Sarnela, N., Petäjä, T., Worsnop, D. R., Kulmala, M., Ehn, M., and Junninen, H.: The role of highly oxygenated molecules (HOMs) in determining the composition of ambient ions in the boreal forest, Atmos. Chem. Phys., 17, 13819-13831, https://doi.org/10.5194/acp-17-138192017, 2017.

Bradshaw, C. J. A. and Warkentin, I. G.: Global estimates of boreal forest carbon stocks and flux, Glob. Planet. Change, 128, 24-30, https://doi.org/10.1016/j.gloplacha.2015.02.004, 2015.

Brandt, J. P., Flannigan, M. D., Maynard, D. G., Thompson, I. D., and Volney, W. J. A.: An introduction to Canada's boreal zone: Ecosystem processes, health, sustainability, and environmental issues, Environ. Rev., 21, 207-226, https://doi.org/10.1139/er2013-0040, 2013.

Carpenter, L. J., MacDonald, S. M., Shaw, M. D., Kumar, R., Saunders, R. W., Parthipan, R., Wilson, J., and Plane, J. M. C.: Atmospheric iodine levels influenced by sea surface emissions of inorganic iodine, Nat. Geosci., 6, 108-111, https://doi.org/10.1038/ngeo1687, 2013. 
Chameides, W. L. and Davis, D. D.: Iodine: Its possible role in tropospheric photochemistry, J. Geophys. Res.-Ocean., 85, 73837398, https://doi.org/10.1029/JC085IC12P07383, 1980.

Charlson, R. J., Lovelock, J. E., Andreae, M. O., and Warren, S. G.: Oceanic phytoplankton, atmospheric sulphur, cloud albedo and climate, Nature, 326, 655-661, https://doi.org/10.1038/326655a0, 1987.

Dal Maso, M., Sogacheva, L., Aalto, P. P., Riipinen, I., Komppula, M., Tunved, P., Korhonen, L., Suur-Uski, V., Hirsikko, A., Kurtén, T., Kerminen, V.-M., Lihavainen, H., Viisanen, Y., Hansson, H.-C., and Kulmala, M.: Aerosol size distribution measurements at four Nordic field stations: Identification, analysis and trajectory analysis of new particle formation bursts, Tellus B, 59, 350-361, https://doi.org/10.1111/j.1600-0889.2007.00267.x, 2007.

Dall Osto, M., Geels, C., Beddows, D. C. S., Boertmann, D., Lange, R., Nøjgaard, J. K., Harrison, R. M., Simo, R., Skov, H., and Massling, A.: Regions of open water and melting sea ice drive new particle formation in North East Greenland, Sci. Rep., 8, 6109, https://doi.org/10.1038/s41598-018-24426-8, 2018.

Ehn, M., Thornton, J. A., Kleist, E., Sipilä, M., Junninen, H., Pullinen, I., Springer, M., Rubach, F., Tillmann, R., Lee, B., Lopez-Hilfiker, F., Andres, S., Acir, I.-H. H., Rissanen, M., Jokinen, T., Schobesberger, S., Kangasluoma, J., Kontkanen, J., Nieminen, T., Kurtén, T., Nielsen, L. B., Jørgensen, S., Kjaergaard, H. G., Canagaratna, M., Maso, M. D., Berndt, T., Petäjä, T., Wahner, A., Kerminen, V.-M. M., Kulmala, M., Worsnop, D. R., Wildt, J., and Mentel, T. F.: A large source of lowvolatility secondary organic aerosol, Nature, 506, 476-479, https://doi.org/10.1038/nature13032, 2014.

Ghirardo, A., Lindstein, F., Koch, K., Buegger, F., Schloter, M., Albert, A., Michelsen, A., Winkler, J. B., Schnitzler, J.-P., and Rinnan, R.: Origin of volatile organic compound emissions from subarctic tundra under global warming, Glob. Chang. Biol., 26, 1908-1925, https://doi.org/10.1111/GCB.14935, 2020.

Hari, P., Aalto, P., Hämeri, K., Kulmala, M., Lahti, T., Luoma, S., Palva, L., Pohja, T., Pulliainen, E., Siivola, E., and Vesala, T.: Air pollution in eastern Lapland: challenge for an environmental measurement station, Silva Fenn., 28, 29-39, https://doi.org/10.14214/SF.A9160, 1994.

He, X., Tham, Y. J., Dada, L., Wang, M., Finkenzeller, H., Stolzenburg, D., Simon, M., Shen, J., Rörup, B., Iyer, S., Rissanen, M., Schobesberger, S., Baalbaki, R., Wang, D., Koenig, T., Jokinen, T., Sarnela, N., Beck, L., Almeida, J., Kuerten, A., Amanatidis, S., Amorim, A., Ataei, F., Baccarini, A., Bertozzi, B., Brilke, S., Caudillo Murillo, L., Chen, D., Chiu, R., Chu, B., Dias, A., Ding, A., Dommen, J., Duplissy, J., El Haddad, I., Flagan, R. C., Gonzalez Carracedo, L., Granzin, M., Hansel, A., Heinritzi, M., Hofbauer, V., Junninen, H., Kangasluoma, J., Kemppainen, D., Kim, C., Kong, W., Krechmer, J., Kvashnin, A., Laitinen, T., Lamkaddam, H., Lee, C. P., Lehtipalo, K., Leiminger, M., Li, Z., Makhmutov, V., Manninen, H., Marie, G., Marten, R., Mauldin III, R. L., Mentler, B., Möhler, O., Müller, T., Onnela, A., Petäjä, T., Pfeifer, J., Philippov, M., Ranjithkumar, A., Salma, I., Scholz, W., Schuchmann, S., Schulze, B., Steiner, G., Stozhkov, Y., Tauber, C., Tomé, A, Väisänen, O., Vazquez-Pufleau, M., Wagner, A. C., Weber, S. K., Nie, W., Winkler, P., Wu, Y., Xiao, M., Yan, C., Ye, Q., Ylisirniö, A., Wang, Y., Zauner-Wieczorek, M., Zha, Q., Zhou, P., Curtius, J., Baltensperger, U., Kulmala,
M., Kerminen, V.-M., Kurtén, T., Donahue, N. M., Volkamer, R., Kirkby, J., Worsnop, D., and Sipilä, M.: Role of iodine oxoacids in atmospheric aerosol nucleation, Science, 371, 589595, https://doi.org/10.1126/SCIENCE.ABE0298, 2021.

Hellén, H., Schallhart, S., Praplan, A. P., Tykkä, T., Aurela, M., Lohila, A., and Hakola, H.: Sesquiterpenes dominate monoterpenes in northern wetland emissions, Atmos. Chem. Phys., 20, 70217034, https://doi.org/10.5194/acp-20-7021-2020, 2020.

Hyttinen, N., Kupiainen-Määttä, O., Rissanen, M. P., Muuronen, M., Ehn, M., and Kurtén, T.: Modeling the Charging of Highly Oxidized Cyclohexene Ozonolysis Products Using Nitrate-Based Chemical Ionization, J. Phys. Chem. A, 119, 6339-6345, 2015.

IPCC: Climate Change 2013: The Physical Science Basis, Contribution of Working Group I to the Fifth Assessment Report of the Intergovernmental Panel on Climate Change, edited by: Stocker, T. F., Qin, D., Plattner, G.-K., Tignor, M., Allen, S. K., Boschung, J., Nauels, A., Xia, Y., Bex, V., and Midgley, P. M., Cambridge University Press, Cambridge, United Kingdom and New York, NY, USA, 1535 pp., http://www.ipcc.ch/report/ar5/wg1/ (last access: 20 October 2021), 2013.

Jen, C. N., McMurry, P. H., and Hanson, D. R.: Stabilization of sulfuric acid dimers by ammonia, methylamine, dimethylamine, and trimethylamine, J. Geophys. Res.-Atmos., 119, 7502-7514, https://doi.org/10.1002/2014JD021592, 2014.

Jokinen, T., Sipilä, M., Junninen, H., Ehn, M., Lönn, G., Hakala, J., Petäjä, T., Mauldin III, R. L., Kulmala, M., and Worsnop, D. R.: Atmospheric sulphuric acid and neutral cluster measurements using CI-APi-TOF, Atmos. Chem. Phys., 12, 4117-4125, https://doi.org/10.5194/acp-12-4117-2012, 2012.

Jokinen, T., Sipilä, M., Richters, S., Kerminen, V.-M. M., Paasonen, P., Stratmann, F., Worsnop, D., Kulmala, M., Ehn, M., Herrmann, H., and Berndt, T.: Rapid autoxidation forms highly oxidized $\mathrm{RO}_{2}$ radicals in the atmosphere, Angew. Chemie Int. Ed., 53, 14596-14600, https://doi.org/10.1002/anie.201408566, 2014.

Jokinen, T., Kontkanen, J., Lehtipalo, K., Manninen, H. E., Aalto, J., Porcar-Castell, A., Garmash, O., Nieminen, T., Ehn, M., Kangasluoma, J., Junninen, H., Levula, J., Duplissy, J., Ahonen, L. R., Rantala, P., Heikkinen, L., Yan, C., Sipilä, M., Worsnop, D. R., Bäck, J., Petäjä, T., Kerminen, V.-M., and Kulmala, M.: Solar eclipse demonstrating the importance of photochemistry in new particle formation, Sci. Rep., 7, 45707, https://doi.org/10.1038/srep45707, 2017.

Jokinen, T., Sipilä, M., Kontkanen, J., Vakkari, V., Tisler, P., Duplissy, E. M., Junninen, H., Kangasluoma, J., Manninen, H. E., Petäjä, T., Kulmala, M., Worsnop, D. R., Kirkby, J., Virkkula, A., and Kerminen, V. M.: Ion-induced sulfuric acid-ammonia nucleation drives particle formation in coastal Antarctica, Sci. Adv., 4, eaat9744, https://doi.org/10.1126/SCIADV.AAT9744, 2018.

Jokinen, T., Lehtipalo, K., Thakur, R. C., Ylivinkka, I., Neitola, K., Sarnela, N., Laitinen, T., Kulmala, M., Petäjä, M., and Sipilä, M.: Long-term measurements of aerosol precursor concentrations in the Finnish sub-Arctic boreal forest, in Atmospheric Physics and Chemistry, Zenodo [data set], https://doi.org/10.5281/zenodo.5879549, 2022.

Junninen, H., Lauri, A., Keronen, P., Aalto, P., Hiltunen, V., Hari, P., and Kulmala, M.: Smart-SMEAR: online data exploration and visualization tool for SMEAR stations, Boreal Environ. Res., 14, 447-457, 2009. 
Junninen, H., Ehn, M., Petäjä, T., Luosujärvi, L., Kotiaho, T., Kostiainen, R., Rohner, U., Gonin, M., Fuhrer, K., Kulmala, M., and Worsnop, D. R.: A high-resolution mass spectrometer to measure atmospheric ion composition, Atmos. Meas. Tech., 3, 10391053, https://doi.org/10.5194/amt-3-1039-2010, 2010.

Kalnay, E., Kanamitsu, M., Kistler, R., Collins, W., Deaven, D., Gandin, L., Iredell, M., Saha, S., White, G., Woollen, J., Zhu, Y., Chelliah, M., Ebisuzaki, W., Higgins, W., Janowiak, J., Mo, K. C., Ropelewski, C., Wang, J., Leetmaa, A., Reynolds, R., Jenne, R., and Joseph, D.: The NCEP/NCAR 40-Year Reanalysis Project, B. Am. Meteorol. Soc., 437-472, https://doi.org/10.1175/15200477(1996)077<0437:TNYRP>2.0.CO;2, 1996.

Kemppinen, J., Niittynen, P., Virkkala, A.-M., Happonen, K., Riihimäki, H., Aalto, J., and Luoto, M.: Dwarf Shrubs Impact Tundra Soils: Drier, Colder, and Less Organic Carbon, Ecosyst., 2021, 1-15, https://doi.org/10.1007/S10021-020-00589-2, 2021.

Kerminen, V., Aurela, M., Hillamo, R. E., and Virkkula, A.: Formation of particulate MSA: deductions from size distribution measurements in the Finnish Arctic, Tellus B, 49, 159-171, https://doi.org/10.1034/j.1600-0889.49.issue2.4.x, 1997.

Kerminen, V.-M., Paramonov, M., Anttila, T., Riipinen, I., Fountoukis, C., Korhonen, H., Asmi, E., Laakso, L., Lihavainen, H., Swietlicki, E., Svenningsson, B., Asmi, A., Pandis, S. N., Kulmala, M., and Petäjä, T.: Cloud condensation nuclei production associated with atmospheric nucleation: a synthesis based on existing literature and new results, Atmos. Chem. Phys., 12, 1203712059, https://doi.org/10.5194/acp-12-12037-2012, 2012.

Kirkby, J., Curtius, J., Almeida, J., Dunne, E., Duplissy, J., Ehrhart, S., Franchin, A., Gagné, S., Ickes, L., Kürten, A., Kupc, A., Metzger, A., Riccobono, F., Rondo, L., Schobesberger, S., Tsagkogeorgas, G., Wimmer, D., Amorim, A., Bianchi, F., Breitenlechner, M., David, A., Dommen, J., Downard, A., Ehn, M., Flagan, R. C., Haider, S., Hansel, A., Hauser, D., Jud, W., Junninen, H., Kreissl, F., Kvashin, A., Laaksonen, A., Lehtipalo, K., Lima, J., Lovejoy, E. R., Makhmutov, V., Mathot, S., Mikkilä, J., Minginette, P., Mogo, S., Nieminen, T., Onnela, A., Pereira, P., Petäjä, T., Schnitzhofer, R., Seinfeld, J. H., Sipilä, M., Stozhkov, Y., Stratmann, F., Tomé, A., Vanhanen, J., Viisanen, Y., Vrtala, A., Wagner, P. E., Walther, H., Weingartner, E., Wex, H., Winkler, P. M., Carslaw, K. S., Worsnop, D. R., Baltensperger, U., and Kulmala, M.: Role of sulphuric acid, ammonia and galactic cosmic rays in atmospheric aerosol nucleation, Nature, 476, 429-433, https://doi.org/10.1038/nature10343, 2011.

Kirkby, J., Duplissy, J., Sengupta, K., Frege, C., Gordon, H., Williamson, C., Heinritzi, M., Simon, M., Yan, C., Almeida, J. J., Tröstl, J., Nieminen, T., Ortega, I. K., Wagner, R., Adamov, A., Amorim, A., Bernhammer, A.-K. K., Bianchi, F., Breitenlechner, M., Brilke, S., Chen, X., Craven, J., Dias, A., Ehrhart, S., Flagan, R. C., Franchin, A., Fuchs, C., Guida, R., Hakala, J., Hoyle, C. R., Jokinen, T., Junninen, H., Kangasluoma, J., Kim, J., Krapf, M., Kurten, A., Laaksonen, A., Lehtipalo, K., Makhmutov, V., Mathot, S., Molteni, U., Onnela, A., Perakyla, O., Piel, F., Petaja, T., Praplan, A. P., Pringle, K., Rap, A., Richards, N. A. D. D., Riipinen, I., Rissanen, M. P., Rondo, L., Sarnela, N., Schobesberger, S., Scott, C. E., Seinfeld, J. H., Sipila, M., Steiner, G., Stozhkov, Y., Stratmann, F., Tomé, A., Virtanen, A., Vogel, A. L., Wagner, A. C., Wagner, P. E., Weingartner, E., Wimmer, D., Winkler, P. M., Ye, P., Zhang, X., Hansel, A.,
Dommen, J., Donahue, N. M., Worsnop, D. R., Baltensperger, U., Kulmala, M., Carslaw, K. S., and Curtius, J.: Ion-induced nucleation of pure biogenic particles, Nature, 533, 521-526, https://doi.org/10.1038/nature17953, 2016.

Kulmala, M., Toivonen, A., Mäkelä, J. M., and Laaksonen, A.: Analysis of the growth of nucleation mode particles observed in Boreal forest, Tellus B, 50, 449-462, https://doi.org/10.1034/j.1600-0889.1998.t01-4-00004.x, 1998.

Kulmala, M., Riipinen, I., Sipilä, M., Manninen, H. E., Petäjä, T., Junninen, H., Dal Maso, M., Mordas, G., Mirme, A., Vana, M., Hirsikko, A., Laakso, L., Harrison, R. M., Hanson, I., Leung, C., Lehtinen, K. E. J., and Kerminen, V. M.: Toward direct measurement of atmospheric nucleation, Science, 80, 89-92, 2007.

Kulmala, M., Kontkanen, J., Junninen, H., Lehtipalo, K., Manninen, H. E., Nieminen, T., Petäjä, T., Sipilä, M., Schobesberger, S., Rantala, P., Franchin, A., Jokinen, T., Järvinen, E., Äijälä, M., Kangasluoma, J., Hakala, J., Aalto, P. P., Paasonen, P., Mikkilä, J., Vanhanen, J., Aalto, J., Hakola, H., Makkonen, U., Ruuskanen, T., Mauldin, R. L., Duplissy, J., Vehkamäki, H., Bäck, J., Kortelainen, A., Riipinen, I., Kurtén, T., Johnston, M. V., Smith, J. N., Ehn, M., Mentel, T. F., Lehtinen, K. E. J., Laaksonen, A., Kerminen, V.-M., and Worsnop, D. R.: Direct observations of atmospheric aerosol nucleation, Science, 339, 943-6, https://doi.org/10.1126/science.1227385, 2013.

Kulmala, M., Ezhova, E., Kalliokoski, T., Noe, S., Vesala, T., Lohila, A., Liski, J., Makkonen, R., Bäck, J., Petäjä, T., and Kerminen, V.-M.: CarbonSink+: Accounting for multiple climate feedbacks from forests, Boreal Environ. Res., 25, 145-159, 2020.

Kürten, A., Rondo, L., Ehrhart, S., and Curtius, J.: Calibration of a chemical ionization mass spectrometer for the measurement of gaseous sulfuric acid, J. Phys. Chem. A, 116, 6375-6386, https://doi.org/10.1021/jp212123n, 2012.

Kürten, A., Jokinen, T., Simon, M., Sipilä, M., Sarnela, N., Junninen, H., Adamov, A., Almeida, J., Amorim, A., Bianchi, F., Breitenlechner, M., Dommen, J., Donahue, N. M., Duplissy, J., Ehrhart, S., Flagan, R. C., Franchin, A., Hakala, J., Hansel, A., Heinritzi, M., Hutterli, M., Kangasluoma, J., Kirkby, J., Laaksonen, A., Lehtipalo, K., Leiminger, M., Makhmutov, V., Mathot, S., Onnela, A., Petäjä, T., Praplan, A. P., Riccobono, F., Rissanen, M. P., Rondo, L., Schobesberger, S., Seinfeld, J. H., Steiner, G., Tomé, A., Tröstl, J., Winkler, P. M., Williamson, C., Wimmer, D., Ye, P., Baltensperger, U., Carslaw, K. S., Kulmala, M., Worsnop, D. R., and Curtius, J.: Neutral molecular cluster formation of sulfuric acid-dimethylamine observed in real time under atmospheric conditions, P. Natl. Acad. Sci. USA, 111, 1501915024, https://doi.org/10.1073/pnas.1404853111, 2014.

Kyrö, E.-M., Väänänen, R., Kerminen, V.-M., Virkkula, A., Petäjä, T., Asmi, A., Dal Maso, M., Nieminen, T., Juhola, S., Shcherbinin, A., Riipinen, I., Lehtipalo, K., Keronen, P., Aalto, P. P., Hari, P., and Kulmala, M.: Trends in new particle formation in eastern Lapland, Finland: effect of decreasing sulfur emissions from Kola Peninsula, Atmos. Chem. Phys., 14, 4383-4396, https://doi.org/10.5194/acp-14-4383-2014, 2014.

Lai, S. C., Williams, J., Arnold, S. R., Atlas, E. L., Gebhardt, S., and Hoffmann, T.: Iodine containing species in the remote marine boundary layer: A link to oceanic phytoplankton, Geophys. Res. Lett., 38, L20801, https://doi.org/10.1029/2011GL049035, 2011.

Lehtipalo, K., Yan, C., Dada, L., Bianchi, F., Xiao, M., Wagner, R., Stolzenburg, D., Ahonen, L. R., Amorim, A., Baccarini, A., 
Bauer, P. S., Baumgartner, B., Bergen, A., Bernhammer, A.-K., Breitenlechner, M., Brilke, S., Buchholz, A., Mazon, S. B., Chen, D., Chen, X., Dias, A., Dommen, J., Draper, D. C., Duplissy, J., Ehn, M., Finkenzeller, H., Fischer, L., Frege, C., Fuchs, C., Garmash, O., Gordon, H., Hakala, J., He, X., Heikkinen, L., Heinritzi, M., Helm, J. C., Hofbauer, V., Hoyle, C. R., Jokinen, T., Kangasluoma, J., Kerminen, V.-M., Kim, C., Kirkby, J., Kontkanen, J., Kürten, A., Lawler, M. J., Mai, H., Mathot, S., Mauldin, R. L., Molteni, U., Nichman, L., Nie, W., Nieminen, T., Ojdanic, A., Onnela, A., Passananti, M., Petäjä, T., Piel, F., Pospisilova, V., Quéléver, L. L. J., Rissanen, M. P., Rose, C., Sarnela, N., Schallhart, S., Schuchmann, S., Sengupta, K., Simon, M., Sipilä, M., Tauber, C., Tomé, A., Tröstl, J., Väisänen, O., Vogel, A. L., Volkamer, R., Wagner, A. C., Wang, M., Weitz, L., Wimmer, D., Ye, P., Ylisirniö, A., Zha, Q., Carslaw, K. S., Curtius, J., Donahue, N. M., Flagan, R. C., Hansel, A., Riipinen, I., Virtanen, A., Winkler, P. M., Baltensperger, U., Kulmala, M., and Worsnop, D. R.: Multicomponent new particle formation from sulfuric acid, ammonia, and biogenic vapors, Sci. Adv., 4, eaau5363, https://doi.org/10.1126/sciadv.aau5363, 2018.

Leino, K., Nieminen, T., Manninen, H. E., Petäjä, T., Kerminen, V.M., and Kulmala, M.: Intermediate ions as a strong indicator of new particle formation bursts in a boreal forest, Boreal Environ. Res, 21, 274-286, 2016.

Levasseur, M.: Impact of Arctic meltdown on the microbial cycling of sulphur., Nat. Geosci., 6, 691-700, 2013.

Mäkelä, J. M., Aalto, P., Jokinen, V., Pohja, T., Nissinen, A., Palmroth, S., Markkanen, T., Seitsonen, K., Lihavainen, H., and Kulmala, M.: Observations of ultrafine aerosol particle formation and growth in boreal forest, Geophys. Res. Lett., 24, 1219-1222, https://doi.org/10.1029/97GL00920, 1997.

Manninen, H. E., Mirme, S., Mirme, A., Petäjä, T., and Kulmala, M.: How to reliably detect molecular clusters and nucleation mode particles with Neutral cluster and Air Ion Spectrometer (NAIS), Atmos. Meas. Tech., 9, 3577-3605, https://doi.org/10.5194/amt-9-3577-2016, 2016.

Maso, M. D., Dal Maso, M., Kulmala, M., Riipinen, I., Wagner, R., Hussein, T., Aalto, P. P., and Lehtinen, K. E. J.: Formation and growth of fresh atmospheric aerosols: Eight years of aerosol size distribution data from SMEAR II, Hyytiälä, Finland, Boreal Environ. Res., 10, 323-336, 2005.

Mauldin, R., Kosciuch, E., Eisele, F., Huey, G., Tanner, D., Sjostedt, S., Blake, D., Chen, G., Crawford, J., and Davis, D.: South Pole Antarctica observations and modeling results: New insights on $\mathrm{HO}_{\mathrm{x}}$ radical and sulfur chemistry, Atmos. Environ., 44, 572-581, https://doi.org/10.1016/j.atmosenv.2009.07.058, 2010.

Mauldin, R. L., Kosciuch, E., Henry, B., Eisele, F. L., Shetter, R., Lefer, B., Chen, G., Davis, D., Huey, G., and Tanner, D.: Measurements of $\mathrm{OH}, \mathrm{HO}_{2}+\mathrm{RO}_{2}, \mathrm{H}_{2} \mathrm{SO}_{4}$, and MSA at the South Pole during ISCAT 2000, Atmos. Environ., 38, 54235437, https://doi.org/10.1016/j.atmosenv.2004.06.031, 2004.

McFiggans, G., Bale, C. S. E., Ball, S. M., Beames, J. M., Bloss, W. J., Carpenter, L. J., Dorsey, J., Dunk, R., Flynn, M. J., Furneaux, K. L., Gallagher, M. W., Heard, D. E., Hollingsworth, A. M., Hornsby, K., Ingham, T., Jones, C. E., Jones, R. L., Kramer, L. J., Langridge, J. M., Leblanc, C., LeCrane, J.-P., Lee, J. D., Leigh, R. J., Longley, I., Mahajan, A. S., Monks, P. S., Oetjen, H., Orr-Ewing, A. J., Plane, J. M. C., Potin, P., Shillings, A. J. L., Thomas, F., von Glasow, R., Wada, R., Whal- ley, L. K., and Whitehead, J. D.: Iodine-mediated coastal particle formation: an overview of the Reactive Halogens in the Marine Boundary Layer (RHaMBLe) Roscoff coastal study, Atmos. Chem. Phys., 10, 2975-2999, https://doi.org/10.5194/acp10-2975-2010, 2010.

Mirme, S. and Mirme, A.: The mathematical principles and design of the NAIS - a spectrometer for the measurement of cluster ion and nanometer aerosol size distributions, Atmos. Meas. Tech., 6, 1061-1071, https://doi.org/10.5194/amt-6-1061-2013, 2013.

Myllys, N., Ponkkonen, T., Passananti, M., Elm, J., Vehkamäki, H., and Olenius, T.: Guanidine: A Highly Efficient Stabilizer in Atmospheric New-Particle Formation, J. Phys. Chem. A, 122, 4717-4729, https://doi.org/10.1021/acs.jpca.8b02507, 2018.

Napari, I., Noppel, M., Vehkamäki, H., and Kulmala, M.: Parametrization of ternary nucleation rates for $\mathrm{H}_{2} \mathrm{SO}_{4}-\mathrm{NH}_{3}-$ $\mathrm{H}_{2} \mathrm{O}$ vapors, J. Geophys. Res.-Atmos., 107, AAC 6-1-AAC 6-6, https://doi.org/10.1029/2002JD002132, 2002.

Nieminen, T., Asmi, A., Maso, M. D., Aalto, P. P., Keronen, P., Kulmala, M., Kerminen, V., Dal maso, M., Aalto, P. P., Keronen, P., Petäjä, T., Kulmala, M., and Kerminen, V.: Trends in atmospheric new-particle formation: 16 years of observations in a boreal-forest environment, Boreal Environ. Res., 19, 191-214, 2014.

O’Dowd, C. D., Jimenez, J. L., Bahreini, R., Flagan, R. C., Seinfeld, J. H., Hämerl, K., Pirjola, L., Kulmala, M., and Hoffmann, T.: Marine aerosol formation from biogenic iodine emissions, Nature, 417, 632-636, 2002.

Paasonen, P., Asmi, A., Petäjä, T., Kajos, M. K., Äijälä, M., Junninen, H., Holst, T., Abbatt, J. P. D. D., Arneth, A., Birmili, W., Van Der Gon, H. D., Hamed, A., Hoffer, A., Laakso, L., Laaksonen, A., Richard Leaitch, W., Plass-Dülmer, C., Pryor, S. C., Räisänen, P., Swietlicki, E., Wiedensohler, A., Worsnop, D. R., Kerminen, V.-M. M., and Kulmala, M.: Warming-induced increase in aerosol number concentration likely to moderate climate change, Nat. Geosci., 6, 438-442, https://doi.org/10.1038/ngeo1800, 2013.

Park, K., Lee, K., Kim, T., Yoon, Y. J., Jang, E., Jang, S., Lee, B., and Hermansen, O.: Atmospheric DMS in the Arctic Ocean and Its Relation to Phytoplankton Biomass, Global Biogeochem. Cy., 32, 351-359, https://doi.org/10.1002/2017GB005805, 2018.

Pirjola, L., Laaksonen, A., Aalto, P., and Kulmala, M.: Sulfate aerosol formation in the Arctic boundary layer, J. Geophys. Res.Atmos., 103, 8309-8321, https://doi.org/10.1029/97JD03079, 1998.

Raso, A. R. W., Custard, K. D., May, N. W., Tanner, D., Newburn, M. K., Walker, L., Moore, R. J., Huey, L. G., Alexander, L., Shepson, P. B., and Pratt, K. A.: Active molecular iodine photochemistry in the Arctic, P. Natl. Acad. Sci. USA, 114, 10053-10058, https://doi.org/10.1073/pnas.1702803114, 2017.

Reyer, C. P. O., Brouwers, N., Rammig, A., Brook, B. W., Epila, J., Grant, R. F., Holmgren, M., Langerwisch, F., Leuzinger, S., Lucht, W., Medlyn, B., Pfeifer, M., Steinkamp, J., Vanderwel, M. C., Verbeeck, H., and Villela, D. M.: Forest resilience and tipping points at different spatio-temporal scales: Approaches and challenges, J. Ecol., 103, 5-15, https://doi.org/10.1111/13652745.12337, 2015.

Riva, M., Rantala, P., Krechmer, J. E., Peräkylä, O., Zhang, Y., Heikkinen, L., Garmash, O., Yan, C., Kulmala, M., Worsnop, D., and Ehn, M.: Evaluating the performance of five differ- 
ent chemical ionization techniques for detecting gaseous oxygenated organic species, Atmos. Meas. Tech., 12, 2403-2421, https://doi.org/10.5194/amt-12-2403-2019, 2019.

Ruuskanen, T., Reissell, M., Keronen, A., Aalto, P. P., Laakso, P. P., Grönholm, L., Hari, T., and Kulmala, P.: Atmospheric trace gas and aerosol particle concentration measurements in Eastern Lapland, Boreal Env. Res., 8, 335-349, 2003.

Ruuskanen, T. M., Kaasik, M., Aalto, P. P., Hõrrak, U., Vana, M., Mårtensson, M., Yoon, Y. J., Keronen, P., Mordas, G., Ceburnis, D., Nilsson, E. D., O’Dowd, C., Noppel, M., Alliksaar, T., Ivask, J., Sofiev, M., Prank, M., and Kulmala, M.: Concentrations and fluxes of aerosol particles during the LAPBIAT measurement campaign at Värriö field station, Atmos. Chem. Phys., 7, 3683-3700, https://doi.org/10.5194/acp-7-3683-2007, 2007.

Schmale, J., Zieger, P., and Ekman, A. M. L.: Aerosols in current and future Arctic climate, Nat. Clim. Chang., 11, 95-105, https://doi.org/10.1038/s41558-020-00969-5, 2021.

Seco, R., Holst, T., Matzen, M. S., Westergaard-Nielsen, A., Li, T., Simin, T., Jansen, J., Crill, P., Friborg, T., Rinne, J., and Rinnan, R.: Volatile organic compound fluxes in a subarctic peatland and lake, Atmos. Chem. Phys., 20, 13399-13416, https://doi.org/10.5194/acp-20-13399-2020, 2020.

Sherwen, T. M., Evans, M. J., Spracklen, D. V., Carpenter, L. J., Chance, R., Baker, A. R., Schmidt, J. A., and Breider, T. J.: Global modeling of tropospheric iodine aerosol, Geophys. Res. Lett., 43, 10012-10019, https://doi.org/10.1002/2016gl070062, 2016.

Sipilä, M., Sarnela, N., Jokinen, T., Henschel, H., Junninen, H., Kontkanen, J., Richters, S., Kangasluoma, J., Franchin, A., Peräkylä, O., Rissanen, M. P., Ehn, M., Vehkamäki, H., Kurten, T., Berndt, T., Petäjä, T., Worsnop, D., Ceburnis, D., Kerminen, V.-M. M., Kulmala, M., O’Dowd, C., and O'Dowd, C.: Molecular-scale evidence of aerosol particle formation via sequential addition of $\mathrm{HIO}_{3}$, Nature, 537, 532-534, https://doi.org/10.1038/nature19314, 2016.

Sipilä, M., Sarnela, N., Neitola, K., Laitinen, T., Kemppainen, D., Beck, L., Duplissy, E.-M., Kuittinen, S., Lehmusjärvi, T., Lampilahti, J., Kerminen, V.-M., Lehtipalo, K., Aalto, P. P., Keronen, P., Siivola, E., Rantala, P. A., Worsnop, D. R., Kulmala, M., Jokinen, T., and Petäjä, T.: Wintertime subarctic new particle formation from Kola Peninsula sulfur emissions, Atmos. Chem. Phys., 21, 17559-17576, https://doi.org/10.5194/acp-21-175592021, 2021.

Sive, B. C., Varner, R. K., Mao, H., Blake, D. R., Wingenter, O. W., and Talbot, R.: A large terrestrial source of methyl iodide, Geophys. Res. Lett., 34, L17808, https://doi.org/10.1029/2007gl030528, 2007.

Spolaor, A., Barbaro, E., Cappelletti, D., Turetta, C., Mazzola, M., Giardi, F., Björkman, M. P., Lucchetta, F., Dallo, F., Pfaffhuber, K. A., Angot, H., Dommergue, A., Maturilli, M., SaizLopez, A., Barbante, C., and Cairns, W. R. L.: Diurnal cycle of iodine, bromine, and mercury concentrations in Svalbard surface snow, Atmos. Chem. Phys., 19, 13325-13339, https://doi.org/10.5194/acp-19-13325-2019, 2019.

Stohl, A.: Characteristics of atmospheric transport into the Arctic troposphere, J. Geophys. Res.-Atmos., 111, D11306, https://doi.org/10.1029/2005JD006888, 2006.

Sulo, J., Sarnela, N., Kontkanen, J., Ahonen, L., Paasonen, P., Laurila, T., Jokinen, T., Kangasluoma, J., Junninen, H., Sip- ilä, M., Petäjä, T., Kulmala, M., and Lehtipalo, K.: Longterm measurement of sub- $3 \mathrm{~nm}$ particles and their precursor gases in the boreal forest, Atmos. Chem. Phys., 21, 695-715, https://doi.org/10.5194/acp-21-695-2021, 2021.

Tarvainen, V., Hakola, H., Hellén, H., Bäck, J., Hari, P., and Kulmala, M.: Temperature and light dependence of the VOC emissions of Scots pine, Atmos. Chem. Phys., 5, 989-998, https://doi.org/10.5194/acp-5-989-2005, 2005.

Tiiva, P., Faubert, P., Michelsen, A., Holopainen, T., Holopainen, J. K., and Rinnan, R.: Climatic warming increases isoprene emission from a subarctic heath, New Phytol., 180, 853-863, https://doi.org/10.1111/J.1469-8137.2008.02587.X, 2008.

Tunved, P., Hansson, H. C., Kerminen, V. M., Ström, J., Dal Maso, M., Lihavainen, H., Viisanen, Y., Aalto, P. P., Komppula, M., and Kulmala, M.: High natural aerosol loading over boreal forests, Science, 312, 261-263, https://doi.org/10.1126/science.1123052, 2006.

Valolahti, H., Kivimäenpää, M., Faubert, P., Michelsen, A., and Rinnan, R.: Climate change-induced vegetation change as a driver of increased subarctic biogenic volatile organic compound emissions, Glob. Chang. Biol., 21, 3478-3488, https://doi.org/10.1111/GCB.12953, 2015.

Vana, M., Komsaare, K., Hõrrak, U., Mirme, S., Nieminen, T., Kontkanen, J., Manninen, H. E., Petäjä, T., Noe, S. M., and Kulmala, M.: Characteristics of new-particle formation at three SMEAR stations, Boreal Environ. Res., 21, 345-362, 2016.

Vehkamäki, H., Dal Maso, M., Hussein, T., Flanagan, R., Hyvärinen, A., Lauros, J., Merikanto, P., Mönkkönen, M., Pihlatie, K., Salminen, K., Sogacheva, L., Thum, T., Ruuskanen, T. M., Keronen, P., Aalto, P. P., Hari, P., Lehtinen, K. E. J., Rannik, Ü., and Kulmala, M.: Atmospheric particle formation events at Värriö measurement station in Finnish Lapland 1998-2002, Atmos. Chem. Phys., 4, 2015-2023, https://doi.org/10.5194/acp-4-20152004, 2004.

Wang, S., Riva, M., Yan, C., Ehn, M., and Wang, L.: Primary Formation of Highly Oxidized Multifunctional Products in the $\mathrm{OH}-$ Initiated Oxidation of Isoprene: A Combined Theoretical and Experimental Study, Environ. Sci. Technol., 52, 12255-12264, https://doi.org/10.1021/acs.est.8b02783, 2018.

Wang, Y. Q., Zhang, X. Y., and Draxler, R. R.: TrajStat: GISbased software that uses various trajectory statistical analysis methods to identify potential sources from long-term air pollution measurement data, Environ. Model. Softw., 24, 938-939, https://doi.org/10.1016/j.envsoft.2009.01.004, 2009.

Yan, C., Nie, W., Äijälä, M., Rissanen, M. P., Canagaratna, M. R., Massoli, P., Junninen, H., Jokinen, T., Sarnela, N., Häme, S. A. K., Schobesberger, S., Canonaco, F., Yao, L., Prévôt, A. S. H., Petäjä, T., Kulmala, M., Sipilä, M., Worsnop, D. R., and Ehn, M.: Source characterization of highly oxidized multifunctional compounds in a boreal forest environment using positive matrix factorization, Atmos. Chem. Phys., 16, 12715-12731, https://doi.org/10.5194/acp-16-12715-2016, 2016.

Yu, H., Ren, L., Huang, X., Xie, M., He, J., and Xiao, H.: Iodine speciation and size distribution in ambient aerosols at a coastal new particle formation hotspot in China, Atmos. Chem. Phys., 19, 4025-4039, https://doi.org/10.5194/acp-19-4025-2019, 2019. 